\title{
Article \\ A Candida parapsilosis Overexpression Collection Reveals Genes Required for Pathogenesis
}

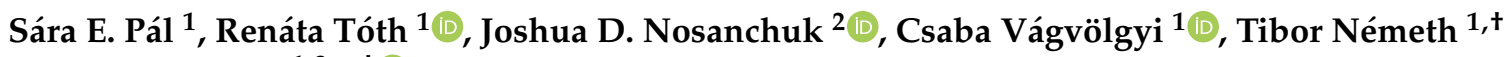 \\ and Attila Gácser $1,3, *,+$ (D) \\ 1 Department of Microbiology, University of Szeged, Közép Fasor, 6726 Szeged, Hungary; \\ palsara0713@gmail.com (S.E.P.); renatatth@gmail.com (R.T.); csaba@bio.u-szeged.hu (C.V.); \\ narvaltm@gmail.com (T.N.) \\ 2 Departments of Medicine and Microbiology and Immunology, Albert Einstein College of Medicine, \\ New York, NY 10461, USA; josh.nosanchuk@einsteinmed.org \\ 3 MTA-SZTE Lendület Mycobiome Research Group, University of Szeged, 6726 Szeged, Hungary \\ * Correspondence: gacsera@bio.u-szeged.hu \\ + T.N. and A.G. contributed equally to this work.
}

Citation: Pál, S.E.; Tóth, R.;

Nosanchuk, J.D.; Vágvölgyi, C.;

Németh, T.; Gácser, A. A Candida parapsilosis Overexpression Collection Reveals Genes Required for Pathogenesis. J. Fungi 2021, 7, 97. https://doi.org/10.3390/jof7020097

Academic Editors: Thomas Lehrnbecher and Hector M. Mora-Montes

Received: 4 December 2020

Accepted: 25 January 2021

Published: 29 January 2021

Publisher's Note: MDPI stays neutral with regard to jurisdictional claims in published maps and institutional affiliations.

Copyright: (c) 2021 by the authors Licensee MDPI, Basel, Switzerland. This article is an open access article distributed under the terms and conditions of the Creative Commons Attribution (CC BY) license (https:// creativecommons.org/licenses/by/ $4.0 /)$

\begin{abstract}
Relative to the vast data regarding the virulence mechanisms of Candida albicans, there is limited knowledge on the emerging opportunistic human pathogen Candida parapsilosis. The aim of this study was to generate and characterize an overexpression mutant collection to identify and explore virulence factors in C. parapsilosis. With the obtained mutants, we investigated stress tolerance, morphology switch, biofilm formation, phagocytosis, and in vivo virulence in Galleria mellonella larvae and mouse models. In order to evaluate the results, we compared the data from the C. parapsilosis overexpression collection analysis to the results derived from previous deletion mutant library characterizations. Of the 37 overexpression C. parapsilosis mutants, we identified eight with altered phenotypes compared to the controls. This work is the first report to identify CPAR2_107240, CPAR2_108840,CPAR2_302400,CPAR2_406400, and CPAR2_602820 as contributors to C. parapsilosis virulence by regulating functions associated with host-pathogen interactions and biofilm formation. Our findings also confirmed the role of CPAR2_109520,CPAR2_200040, and CPAR2_500180 in pathogenesis. This study was the first attempt to use an overexpression strategy to systematically assess gene function in C. parapsilosis, and our results demonstrate that this approach is effective for such investigations.
\end{abstract}

Keywords: Candida parapsilosis; gene overexpression; mutant collection; virulence factors

\section{Introduction}

Candida species are responsible for the vast majority of systemic fungal nosocomial infection cases. Numerous studies from different parts of the world report increasing rates of systemic candidiasis [1-4]. Non-albicans Candida (NAC) species such as C. glabrata, C. parapsilosis, C. krusei, C. auris, and C. tropicalis have significantly contributed to this continuous rise in the number of candidiasis cases, which highlights the importance of these emerging species [5-7]. Remarkable changes in medical practice that subvert host effector responses, such as the robust use of immunosuppressive therapies, can also affect the epidemiology of a pathogenic species and increase the incidence of fungal infections [8-10].

There is an enormous amount of data available in the literature on the virulence mechanisms of C. albicans, while our knowledge lags behind for emerging NAC opportunistic human pathogens, such as C. parapsilosis [11]. Although C. parapsilosis is a commensal yeast of the normal human skin, it can, in contrast to the strict association of C. albicans with humans, also survive in diverse environments. C. parapsilosis' increasing role in low birth weight neonatal infections highlights the importance of performing extensive surveys of its physiology and virulence factors [12-15]. C. parapsilosis is able to form pseudohypha, 
but not true hypha, and its elevated tolerance to echinocandins are additional specific attributions with clinical relevance $[16,17]$. So far, several groups have explored specific gene functions in C. parapsilosis [18-20]. The first genome sequence of a C. parapsilosis strain (CDC317) was published in 2009 [21]. Later, three more strains derived from human and environmental sources were also sequenced and comprehensively analyzed, enabling further investigations of large scale targeted genomic alterations in this species [21,22]. These and other studies also revealed genomic and phenotypic alterations between C. albicans and C. parapsilosis, suggesting that these two pathogenic species have evolved different strategies to invade the host [23,24]. According to the Candida Genome Database (CGD) only $1.35 \%$ of the protein coding genes of $C$. parapsilosis have been verified to date, while this number is $27.9 \%$ in the case of $C$. albicans $[25,26]$. Taking into account the unique and distinctive interspecies characteristics of $C$. parapsilosis in the Candida clade, further investigation is urgently needed to reveal factors associated with the pathobiological mechanisms of the species.

The conventional method to reveal gene function is the deletion of a given gene and observation of the phenotype of the knock out (KO) mutant. Comprehensive $\mathrm{KO}$ mutant libraries and their characterizations are accessible for many organisms, including C. parapsilosis [27-30]. Pathogenesis associated gene functions such as biofilm formation, phenotypic profile, and transition or genes responsible for drug resistance or transcriptional regulator networks have also been identified in both C. albicans and C. parapsilosis using $\mathrm{KO}$ methods. Even in silico gene deletion for drug development has been carried out with C. albicans [31]. This approach was aided by the rapid evolution of the molecular techniques replacing the laborious CaSAT1 flipper, or the double auxotrophy complementation approaches with CRISPR/Cas9 system that simplified the generation of loss of function mutations $[18,28,32-35]$. However, in some cases, the resulting phenotype achieved by gene deletion has been uninformative, or the $\mathrm{KO}$ approach has failed, especially when essential genes are in question. Furthermore, in diploid organisms deletion of both alleles for the targeted gene is required. The artificial overexpression (OE) of a gene can circumvent the aforementioned drawbacks of the $\mathrm{KO}$ method. In addition to this, an OE strategy can be utilized to map regulatory rate-limiting steps in gene interaction studies [36]. Systematic library analysis as well as specific gene examination studies have been published using OE mutant strains in many organisms [37-41]. Genes involved in biological processes associated with fungal pathogenesis, such as biofilm formation, invasive hyphal growth or drug resistance, have also been successfully identified using this approach in C. albicans and other Candida species [42-44]. Moreover, the OE approach can also complement the KO library screens to explore and validate the function of a gene [36,45-48].

Although extensive studies in gene OE in Saccharomyces cerevisiae and C. albicans have enriched our knowledge on their fitness and virulence [49-52], no such an effort has yet been achieved in the case of the neonatal pathogen C. parapsilosis. Therefore, we have generated and characterized an $\mathrm{OE}$ collection in C. parapsilosis using a recently adapted system by Németh and co-workers [53] and explored the collection in order to reveal novel virulence traits.

\section{Materials and Methods}

\subsection{Strains and Growth Conditions}

C. parapsilosis and Escherichia coli strains used in this study are listed in Table S1. Yeast strains were stored at $-80{ }^{\circ} \mathrm{C}$ in YPD $(0.5 \%(\mathrm{~m} / \mathrm{v})$ yeast extract, $1 \%(\mathrm{~m} / \mathrm{v})$ peptone, and $1 \%(m / v)$ D-glucose) media supplemented with $20 \%(v / v)$ glycerol. Yeast strains were routinely maintained on YPD plates supplemented with $2 \%(\mathrm{~m} / v)$ agarose and $100 \mathrm{unit} / \mathrm{mL}$ Penicillin-Streptomycin (PS) solution and maintained at $4{ }^{\circ} \mathrm{C}$. For the experiments, fungal strains were grown in YPD media supplemented with $100 \mathrm{unit} / \mathrm{mL}$ PS in an orbital shaker at $30^{\circ} \mathrm{C}$ overnight, then $1 \mu \mathrm{L}$ of the overnight culture was transferred into $3 \mathrm{~mL}$ of fresh YPD media and cultivated under the same conditions overnight. Two milliliters of the 
suspension was collected and washed twice with sterile $1 \times$ PBS, diluted then counted with a Burker-chamber. Specific cell concentrations were set using $1 \times$ PBS.

Prototroph transformants were selected and maintained on solid minimal media, containing YNB $(0.19 \% \mathrm{~m} / v$ Yeast Nitrogen Base without amino acids) media supplemented with $2 \%(\mathrm{~m} / \mathrm{v})$ glucose, $2 \%(\mathrm{~m} / \mathrm{v})$ agar, $100 \mathrm{unit} / \mathrm{mL}$ PS, and $10 \%(v / v) 10 \times$ Dropout (DO) amino acid solution (without leucine) [28].

E. coli strains were grown on LB plates $(1 \%(\mathrm{~m} / \mathrm{v}) \mathrm{NaCl}, 1 \%(\mathrm{~m} / \mathrm{v})$ tryptone, $0.5 \%(\mathrm{~m} / \mathrm{v})$ yeast extract, and $2 \%(\mathrm{~m} / \mathrm{v})$ agar) supplemented with $10 \mu \mathrm{g} / \mathrm{mL}$ tetracycline for strain $2 \mathrm{~T} 1$. Selection of colonies bearing the plasmids was carried out on LB plates supplemented with $50 \mu \mathrm{g} / \mathrm{mL}$ kanamycin A or $100 \mu \mathrm{g} / \mathrm{mL}$ ampicillin. Plasmid extraction from $2 \mathrm{~T} 1$ or DB3.1 E. coli strains was performed by cultivating transformants in $2 \mathrm{~mL}$ LB liquid media in an orbital shaker at $37^{\circ} \mathrm{C}$ with the appropriate antibiotics overnight.

Dulbecco's modified eagle's medium (DMEM) $+10 \%(v / v)$ heat-inactivated fetal bovine serum (HI FBS) + 100 unit/mL PS media was used for pseudohypha detection experiments and for the maintenance of the J774.2 murine cell line.

\subsection{Construction of the Overexpression Cassettes}

Overexpression constructs were generated using Gateway ${ }^{\mathrm{TM}}$ cloning method with $\mathrm{pDONR}^{\mathrm{TM}} 221$ for BP and pDCpOE-L-N5L for LR cloning [53]. Target ORFs were amplified with an attB1 site at the $5^{\prime}$ end, and an attB2 site at the $3^{\prime}$ end. Additionally, the $3^{\prime}$ end also contained a $20 \mathrm{nt}$ long unique bar code sequence to enable rapid identification by molecular methods (Table S1). BP and LR cloning were performed according to the manufacturer's instructions. E. coli strain $2 \mathrm{~T} 1$ was transformed with $\mathrm{BP}$ and LR cloning products and used to propagate pENTRY and pECpOE, respectively, while pDONR ${ }^{\mathrm{TM}} 221$ and pDCpOE-LN5L plasmids were propagated in strain DB3.1.

\subsection{Generation of the Overexpression Mutants}

The $p E C$ POE-ORF-L-N5L plasmids were linearized by StuI digestion overnight, precipitated, washed with 70\% $(v / v)$ ethanol, air-dried, and suspended in $10 \mu \mathrm{L}$ distilled water. Three micrograms of the linearized plasmid was used to transform the leucine auxotroph derivative of $C$. parapsilosis (CPL2) using the ssDNA/LiAc/PEG mediated heat-shock method as described by Holland and co-workers [28]. Cells were plated onto minimal media and incubated for three days at $30^{\circ} \mathrm{C}$.

\subsection{Validation of the Mutant Strains}

To verify the proper integration of the cassettes, we first performed rapid DNA isolation followed by colony PCR involving primers specific to the given ORF and downstream from the site of the integration [28]. See primer sequences in Table S1. Further verification was managed using Southern blot. Briefly, $10 \mu \mathrm{g}$ of total genomic DNA was digested with EcoRI overnight. A digoxigenin labeled CpN5L downstream probe was generated by amplifying the given region from C. parapsilosis CLIB214 genomic DNA with CpN5LDo1SouFor and CpN5LDo2SouRev primers using the DIG DNA Labeling Kit (Roche) according to the manufacturer's instructions (Table S1). For real-time PCR analysis, extraction and reverse transcription of the RNA to cDNA was performed using Ambion, Ribopure ${ }^{\mathrm{TM}}$-Yeast RNA Isolation Kit, and the RevertAid First Strand cDNA Synthesis Kit (ThermoFisher), respectively, according to the instructions of the manufacturers. Real-time qPCR was carried out as previously described [29] in a Bio-Rad Real-Time PCR detection system. Data were normalized to CLIB214 wild type strain, and relative transcription levels were determined using the housekeeping gene CPTUB4 (CPAR2_500510) as an internal control. The RNA extraction was performed from the pool of three independent cultures mixed in an even ratio. To evaluate the results, the $2^{-\Delta \Delta C q}$ comparison method was used with Bio-Rad CFX Manager software. Primers for these experiments are listed in Table S1. 


\subsection{Characterization of the OE Mutant Strains}

\subsubsection{Growth Kinetics Measurements in Liquid Cultures}

The experiments were performed three times except for those mutants that showed no difference compared to the control in the first two experiments. Three different control C. parapsilosis strains-the wild type strain (CLIB214), the reintegrated strain of the double auxotroph strain (CPRI), and the mCherry ${ }^{\mathrm{OE}}$ mutant-were used in growth kinetics, stress tolerance, and antifungal susceptibility experiments.

To monitor the growth capabilities of the generated mutants, kinetic studies were performed in YPD + 100 unit/mL PS and YNB $(0.67 \%$ Yeast Nitrogen Base without amino acids) $+0.5 \%$ glucose +100 unit $/ \mathrm{mL}$ PS liquid medium under static conditions at $30^{\circ} \mathrm{C}$ for $24 \mathrm{~h}$, and the $\mathrm{OD}_{600}$ was determined every hour after one-minute of shaking (200 rpm) (SpectroStar Nano). Tests were performed three times in triplicates in 48-well plates. Initial concentrations were determined at $5 \times 10^{5}$ cells $/ \mathrm{mL}$, where $100 \mu \mathrm{L}$ of the suspension was added to each well loaded with $900 \mu \mathrm{L}$ liquid medium.

\subsubsection{Viability Tests under Different Stress Conditions on Solid Media}

Viability of the strains was tested under the stress conditions listed in Table S2. Four step ten-fold dilutions were prepared with $10^{5}$ to $10^{2}$ cells per $5 \mu \mathrm{L}$. Growth was examined at 30 and $37^{\circ} \mathrm{C}$ after $48 \mathrm{~h}$ of incubation. Heat dependency was examined by incubating the cells at $20,25,30,37$, and $40^{\circ} \mathrm{C}$ on YPD solid medium. In addition, growth was investigated on solid minimal media $(0.19 \%$ YNB $+0.5 \%$ glucose $+100 \mathrm{unit} / \mathrm{mL}$ PS) with or without the addition of $10 \%(v / v)$ HI FBS at 30 and $37^{\circ} \mathrm{C}$.

\subsubsection{Morphology Switch and Pseudohypha Forming Capacity}

The morphology of OE strains was examined under a light microscope. Prior to examination, each strain was grown in liquid YPD +100 unit/mL PS media, collected, washed three times, suspended in $1 \times$ PBS solution, and pipetted onto glass slides.

The pseudohypha forming capacity was investigated after growing the cells in liquid YPD + $100 \mathrm{unit} / \mathrm{mL}$ PS and DMEM $+10 \%(v / v)$ HI FBS $+100 \mathrm{unit} / \mathrm{mL}$ PS media at $37^{\circ} \mathrm{C}$, $5 \%(v / v) \mathrm{CO}_{2}$ for $24-48 \mathrm{~h}$. After one day of incubation, the samples were examined by light microscopy. After two days, each sample was measured with Amnis ${ }^{\circledR}$ FlowSight ${ }^{\circledR}$ flow cytometer. Data were analyzed by the IDEAS Software (Amnis).

\subsubsection{Biofilm Assay}

Biofilm inducing conditions were $0.67 \%(\mathrm{~m} / \mathrm{v}) \mathrm{YNB}+0.5 \%(\mathrm{~m} / \mathrm{v})$ glucose $+100 \mathrm{unit} / \mathrm{mL}$ PS liquid media incubated at $37^{\circ} \mathrm{C}$ in the presence of $5 \%(v / v) \mathrm{CO}_{2}$ for $48 \mathrm{~h}$ without shaking. Experiments were carried out in $10 \%$ FBS precoated 96-well plates (polystyrene). After two washing steps, 20-20 $\mu \mathrm{L} 5 \mathrm{mg} / \mathrm{mL}$ 3-(4,5-dimethylthiazol-2-yl)-2,5-diphenyltetrazolium bromide (MTT) solution was added to the suspensions and incubated for $5 \mathrm{~h}$ under the same conditions followed by two washing steps with $1 \times$ PBS. Insoluble (formazan) residue was formed, which was dissolved in DMSO for 10-15 min, and OD $_{540}$ were detected by spectrophotometry (SpectroStar Nano). Cell-free culturing media with MTT solution and MTT-free cell suspension samples were applied as controls. At least eight parallels were used in at least three experiments.

\subsubsection{Antifungal Susceptibility}

Strains were prepared as described above then the concentration was adjusted to $3 \times 10^{4} \mathrm{cell} / \mathrm{mL}$ by suspending the cells in Roswell Park Memorial Institute 1640 medium supplemented with $34.53 \mathrm{~g} / \mathrm{L}$ 4-Morpholinepropanesulfonic acid (RPMI-MOPS). Two-fold dilutions of anidulafungin, caspofungin, and micafungin were prepared. Final drug concentrations were from $8 \mu \mathrm{g} / \mathrm{mL}$ to $0.0156 \mu \mathrm{g} / \mathrm{mL}$ with $3 \times 10^{3}$ fungal cells in $200 \mu \mathrm{L}$ final volume of RPMI-MOPS. Cells were incubated at $30^{\circ} \mathrm{C}$ without shaking and monitored after 24 and $48 \mathrm{~h}$. Minimum inhibitory concentration (MIC) values were determined according to the M27-A3 protocol, and MIC values were defined by the M27-S4 supplementary docu- 
ment $[54,55]$. MIC values for the applied drugs were defined as the lowest concentrations that resulted in at least $50 \%$ growth reduction. Experiments were performed in triplicates. In addition to mCherry $\mathrm{OE}$, CPRI, and CLIB214 C. parapsilosis strains, a C. krusei strain with known antifungal susceptibility was also included as a control.

\subsubsection{Phagocytosis Assay}

The murine macrophage-like cell line J774.2 and each mutant strain were grown as previously described. The fungi were stained with Alexa Fluor ${ }^{\mathrm{TM}} 488$ succinimidyl ester dye (Invitrogen) prior to the experiments, according to Papp and colleagues [17]. We then infected J774.2 macrophages with stained yeast cells using the multiplicity of infection (MOI) of 5:1 (pathogen:host) and co-incubated the cells at $37^{\circ} \mathrm{C}, 5 \%(v / v) \mathrm{CO}_{2}$ for $1 \mathrm{~h}$. The wild type strain and non-infected J774.2 macrophages were used as controls to exclude autofluorescence. Samples were measured with Amnis ${ }^{\circledR}$ FlowSight ${ }^{\circledR}$ flow cytometer.

\subsubsection{In Vivo Galleria mellonella Infection Model}

The larvae (BioSystems Technology-TruLarv ${ }^{\mathrm{TM}}$, Exeter, Devon, England) were kept at $4{ }^{\circ} \mathrm{C}$ and transferred to $30^{\circ} \mathrm{C}$ one day before the experiment. Mutant yeast strains were tested at least two times with 20 larvae per sample. Concentrations of $\mathrm{OE}$ strains were adjusted to $5 \times 10^{7}$ cell $/ \mathrm{mL}$. Each larva was injected with $10 \mu \mathrm{L}$ suspension containing $5 \times 10^{5}$ cells and incubated at $30^{\circ} \mathrm{C}$ in dark. Survival was monitored daily for 10 days. Larvae injected with wild type strain, non-injected (witness) G. mellonella larvae, and $1 \times$ PBS injected larvae were used as controls.

\subsubsection{Cell Wall Composition Assay}

To investigate putative alterations in certain cell wall components of the selected mutants (CPAR2_107240 ${ }^{\mathrm{OE}}, \mathrm{CPAR} 2108840^{\mathrm{OE}}, \mathrm{CPAR2} 109520^{\mathrm{OE}}, \mathrm{CPAR2} 200040^{\mathrm{OE}}, \mathrm{CPAR} 2$ $302400^{\circ}$, CPAR2_406400 ${ }^{\mathrm{OE}}, \mathrm{CPAR2} 5500180^{\mathrm{OE}}$, and CPAR2_602820 ${ }^{\mathrm{OE}}$ ), ConA-FITC (SigmaAldrich, St. Louis, MO, USA), Calcofluor white (Sigma-Aldrich, St. Louis, MO, USA), and WGA-FITC (Sigma-Aldrich, St. Louis, MO, USA) were applied. Samples were prepared as previously described by Tóth and colleagues [29]. The first fluorescent dye mix contained $4 \mu \mathrm{L} 2.5 \mathrm{mg} / \mathrm{mL}$ ConA-FITC and $0.5 \mu \mathrm{L} 1 \mathrm{mg} / \mathrm{mL}$ Calcofluor white while the second contained $0.25 \mu \mathrm{L} 2 \mathrm{mg} / \mathrm{mL}$ WGA-FITC in the final $100 \mu \mathrm{L}$ volume of $1 \% \mathrm{BSA}+1 \times$ PBS solution. For detection, we used a Zeiss Axio Observer fluorescent microscope, and the means of the different fluorescent dyes were recorded with an Amnis ${ }^{\circledR}$ FlowSight ${ }^{\circledR}$ flow cytometer.

\subsubsection{In Vivo Mouse Infection Model}

Selected mutant and wild type strains were prepared as described above, and cell concentrations were set to $2 \times 10^{8} / \mathrm{mL}$. Mus musculus BALB/c 7-8-week-old females (BRC, Szeged, Hungary, XVI./2015) were infected with $100 \mu \mathrm{L}$ suspensions through their lateral tail veins. Animals were monitored daily and sacrificed after three days. Brain, liver, spleen, and kidneys were isolated, weighed, and homogenized under sterile conditions in $1 \mathrm{x}$ sterile PBS. Following subsequent dilutions, $50-50 \mu \mathrm{L}$ of samples were plated on YPD plates and incubated for two days at $30^{\circ} \mathrm{C}$. Colony-forming units (CFUs) were determined, and the results were calculated and expressed in $\mathrm{CFU} / \mathrm{g}$ tissue units. Four or five parallel animals were tested in two independent experiments.

\subsection{Ethics Statement}

Animal experiments were performed according to Hungarian national animal ethics guidelines (guideline 1998, XXVIII; 40/2013) and European animal ethics guidelines (guideline 2010/63/EU). The procedures were licensed by the Animal Experimentation and Ethics Committee of the Biological Research Centre of the Hungarian Academy of Sciences and the Hungarian National Animal Experimentation and Ethics Board (clearance number XVI./03521/2011), with the University of Szeged granting permission XII./00455/2011 and XVI./3646/2016 to work with mice. 


\subsection{Statistical Analysis}

Statistical analysis was performed using GraphPad Prism 7 software. For the biofilm assay and the phagocytosis analyses, we used one-way ANOVA, Dunnett's multiple comparisons test. To evaluate the results of the G. mellonella infection experiments Log-rank (Mantel-Cox) tests and, for the assessment of fungal infection in mice, Mann-Whitney tests were used. Statistically significant differences were considered at $p$-values of $\leq 0.05$ $\left.{ }^{*} p \leq 0.05 ;{ }^{* *} p \leq 0.01 ;{ }^{* * *} p \leq 0.001 ;{ }^{* * * *} p \leq 0.0001\right)$.

\section{Results}

\subsection{Generation of an Overexpression Mutant Collection in C. parapsilosis}

The examined ORFs were preselected according to our preliminary experiments and related data from the literature (Table S3). Transcriptional analysis of fungi co-incubated with THP-1 human monocytes was performed as previously described by Tóth and coworkers in order to identify genes related to pathogenesis based on their altered expression patterns during infection [29]. We selected 18 differentially expressed genes and 19 additional genes that also have known virulence-related ortholog functions in C. albicans or in S. cerevisiae based on literature prior to generating the $\mathrm{OE}$ mutant collection. The 18 differentially expressed genes were also tested in previous KO mutant library analyses in C. parapsilsosis $[19,28,29]$.

To generate overexpression mutants, the Gateway ${ }^{\mathrm{TM}}$ system was used. Our work is based on the previous work of Chauvel and colleagues with C. albicans [50], which we modified and optimized for C. parapsilosis [53]. Selected ORFs were amplified along with a $20 \mathrm{nt}$ long bar code (See Table S1 TAG sequences) in the non-transcribed region to enable subsequent identification by molecular methods. Within the expression vector, the cloned ORFs were under the regulation of the TDH3 promoter of $C$. albicans (Figure S1). The plasmid was then linearized with $S t u I$ digestion. The linearized plasmid (or integrative cassette) was then integrated into the CpNEUT5L (CpN5L) intergenic region of C. parapsilosis (Figure S2). We targeted the CpN5L region because, in contrast to the ortholog of RPS1, this locus not only provides a strong homogenous expression for exogenous constructs, but it does not affect the fitness of the transformed/modified strain $[53,56]$. The expression vector utilizes the $C$. maltosa LEU2 marker for selection that is compatible with the leucine auxotroph laboratory strain of $C$. parapsilosis CPL2 [28]. A total of 37 ORFs were amplified, BP cloned, and then sequenced to ensure that there were no SNPs (single-nucleotide polymorphism) present causing any amino acid alterations. The correct integration of the linearized plasmids was verified by colony PCR and Southern-blot analysis (Figure S2). The relative expression of each gene was measured using qPCR and compared to CLIB214. We found that the expression levels varied across a wide range with increases from 2.6-fold to 675.7 -fold (Table 1).

\subsection{Characterization of the Generated OE Mutant Strains}

3.2.1. Overexpression Does Not Affect Growth in either Complete or in Minimal Liquid Media

We applied three control strains in these experiments. CPRI is the C. maltosa LEU2 complemented derivative of the leucine auxotroph CPL2 strain, which was used to generate the mutant collection [28]. CLIB214 is a prototroph isolate and the parental strain of CPL2. We also included an mCherry fluorescent protein-expressing strain as a control OE strain (mCherry ${ }^{\mathrm{OE}}$ ), which was generated using the same procedure. We found this pertinent because expressing an irrelevant gene (coding a "neutral" protein) in terms of virulence would imitate the same load on the expression machinery, which itself might have an effect on the physiological and virulence properties of the fungus [53]. 
Table 1. Real-time qPCR-based overexpression data (fold-change, relative normalized expression-RNE) of the created mutant strains. Data were normalized to the CLIB214 wild type strain. Relative transcription levels were determined using the housekeeping gene CPTUB4 (CPAR2_500510) as an internal control. Measurements were performed in three statistical parallels. The $2^{-\triangle \Delta \mathrm{Cq}}$ comparison method was used with Bio-Rad CFX Manager software. (Cp-Candida parapsilosis; Ca-C. albicans; Sc-Saccharomyces cerevisiae).

\begin{tabular}{|c|c|c|c|c|c|}
\hline Gene Name & Ortholog Name & RNE & Gene Name & Ortholog Name & RNE \\
\hline CPAR2_100460 & СpHBT4 & $122.5 \pm 17.7$ & CPAR2_302400 & ScMGT1 & $424.4 \pm 90.5$ \\
\hline CPAR2_100470 & СpHBT3 & $18.6 \pm 0.9$ & CPAR2_303240 & ScPFA5 & $44.7 \pm 2.8$ \\
\hline CPAR2_100540 & CaHAP5 & $7.6 \pm 0.9$ & CPAR2_303730 & ScTHR1 & $66.1 \pm 26$ \\
\hline CPAR2_104420 & ScLTE1 & $378.5 \pm 22.1$ & CPAR2_400270 & ScHIT1 & $31.6 \pm 2.3$ \\
\hline CPAR2_105250 & CaPHO85 & $44.8 \pm 3.5$ & CPAR2_406400 & ScRPA12 & $41.7 \pm 7.3$ \\
\hline CPAR2_107020 & CaHHF1 & $118.2 \pm 11.0$ & CPAR2_500180 & ScKIN3 & $675.7 \pm 89.3$ \\
\hline CPAR2_107240 & CaKTR4/MNT4 & $70.4 \pm 12.4$ & CPAR2_500360 & ScAMS1 & $37.2 \pm 2.6$ \\
\hline CPAR2_108840 & ScSPS1 & $50.5 \pm 9.6$ & CPAR2_501400 & $\mathrm{CaCWH} 41$ & $90.0 \pm 11.2$ \\
\hline CPAR2_109520 & CaTUP1 & $19.1 \pm 4.5$ & CPAR2_503290 & CaRAD53 & $218.4 \pm 25.9$ \\
\hline CPAR2_200040 & - & $212.2 \pm 17.3$ & CPAR2_503760 & ScTMA46 & $7.3 \pm 0.7$ \\
\hline CPAR2_200390 & CaSPT3 & $9.0 \pm 0.6$ & CPAR2_602370 & ScRAD18 & $17.3 \pm 2.1$ \\
\hline CPAR2_201920 & ScMNT2 & $7.3 \pm 1.1$ & CPAR2_602820 & CaFCA1 & $28.4 \pm 8.4$ \\
\hline CPAR2_204840 & СpHBT2 & $8.9 \pm 1.8$ & CPAR2_602840 & ScTFB4 & $176.7 \pm 30.6$ \\
\hline CPAR2_205060 & $\mathrm{CaCDC} 28$ & $30.6 \pm 5.6$ & CPAR2_700550 & ScRSC8 & $4.5 \pm 0.5$ \\
\hline CPAR2_208600 & $\mathrm{CaCPH1}$ & $44.5 \pm 3.6$ & CPAR2_703840 & ScSLM5 & $52.5 \pm 8.4$ \\
\hline CPAR2_209240 & CaCDC19/PYK & $2.6 \pm 0.0$ & CPAR2_804030 & ScGSC2 & $134.6 \pm 29.9$ \\
\hline CPAR2_209520 & CaMKK2 & $7.8 \pm 1.3$ & CPAR2_805930 & CaTEC1 & $34.5 \pm 6.9$ \\
\hline CPAR2_300080 & ScADK2 & $134.8 \pm 7.3$ & CPAR2_806950 & ScNOB1 & $65.7 \pm 9.9$ \\
\hline CPAR2_301360 & CaPMR1 & $38.9 \pm 3.1$ & & & \\
\hline
\end{tabular}

First, we tested if the overexpression of the selected genes had any effect on the viability of the mutants. To achieve this, we cultivated the strains in YPD and YNB minimal liquid media for $24 \mathrm{~h}$ and compared the growth curves to that of the control strains. As a result, we found no significant differences between the growth capacity of the generated mutants compared to the three control strains (Figures S3 and S4), suggesting that the overexpression of these genes did not alter the viability of the OE mutants. Therefore, we included all the strains in the subsequent experiments to examine potential alterations in their virulence and fitness under different stress-inducing conditions, and as a control, we included the wild type CLIB214 strain unless otherwise stated.

\subsubsection{Overexpression of Certain Genes Affects Viability under Specific Stress Conditions}

As a surrogate for the yeast's ability to resist severe growth restrictive conditions such as elevated temperatures, different $\mathrm{pH}$ levels, or oxidative stressors in the host, a wide variety of the aforementioned stress conditions were applied in vitro to the $\mathrm{OE}$ collection on YPD solid media (Table S2). Growth was monitored both at 30 and $37^{\circ} \mathrm{C}$, which represent the regular cultivation temperature of the fungus and the physiological body temperature of humans, respectively. The viability of the mutants was also tested at different temperatures, including $20,25,30,37$, and $40{ }^{\circ} \mathrm{C}$ on YPD agar plates and at $30,37^{\circ} \mathrm{C}$ on YNB and YNB + FBS solid agar. In this range of temperature, we could not detect any difference in the growth of the examined mutants in comparison to the applied controls, either on complete or minimal media (Figure S5). 
Three out of the 37 overexpression mutants showed alteration in their fitness under at least one condition (Table 2). The three control strains had similar growth patterns under different stress conditions (Figure S6). Reduced growth was detected in the presence of Calcofluor white (CFW) or Congo red (CR) with CPAR2_200040 ${ }^{\mathrm{OE}}$ and CPAR2_302400 ${ }^{\mathrm{OE}}$. Susceptibility to sodium dodecyl sulfate (SDS) occurred in the case of CPAR2_109520 OE and CPAR2_302400 ${ }^{\mathrm{OE}}$, while caffeine intolerance was detected with the CPAR2_302400 OE mutant (Table 2). The applied stressors like CFW, CR, and caffeine have negative effects on the wall biogenesis and activate cell wall integrity (CWI) signaling via different components of the pathway. SDS is a membrane perturbing agent, and it has an effect on the integrity of the cell wall as well. Also, SDS can induce protein denaturation and cell lysis [57].

Table 2. The heat map shows the results of the spot assay analyses (CFW—Calcofluor white; CR—Congo red; black—no growth; red—strong defect; orange—-medium defect; yellow—slight defect; grey—no difference).

\begin{tabular}{|c|c|c|c|c|c|c|c|c|c|c|c|c|c|c|c|c|c|c|}
\hline \multirow{2}{*}{$\begin{array}{c}\text { Stressor } \\
\mathrm{T}\left({ }^{\circ} \mathrm{C}\right)\end{array}$} & \multicolumn{2}{|c|}{$\begin{array}{l}\text { Caffeine } \\
(10 \mathrm{mM})\end{array}$} & \multicolumn{2}{|c|}{$\begin{array}{c}\text { CFW } \\
(25 \mu \mathrm{g} / \mathrm{mL})\end{array}$} & \multicolumn{2}{|c|}{$\begin{array}{c}\text { CFW } \\
(50 \mu \mathrm{g} / \mathrm{mL})\end{array}$} & \multicolumn{2}{|c|}{$\begin{array}{c}\mathrm{CR} \\
(10 \mu \mathrm{g} / \mathrm{mL})\end{array}$} & \multicolumn{2}{|c|}{$\begin{array}{c}\mathrm{CR} \\
(25 \mu \mathrm{g} / \mathrm{mL})\end{array}$} & \multicolumn{2}{|c|}{$\begin{array}{c}\text { CR } \\
(50 \mu \mathrm{g} / \mathrm{mL})\end{array}$} & \multicolumn{2}{|c|}{$\begin{array}{c}\text { CR } \\
(75 \mu \mathrm{g} / \mathrm{mL})\end{array}$} & \multicolumn{2}{|c|}{$\begin{array}{c}\text { CR } \\
(100 \mu \mathrm{g} / \mathrm{mL})\end{array}$} & \multicolumn{2}{|c|}{$\begin{array}{c}\text { SDS } \\
(0.04 \% \mathrm{~m} / \mathrm{v})\end{array}$} \\
\hline & 30 & 37 & 30 & 37 & 30 & 37 & 30 & 37 & 30 & 37 & 30 & 37 & 30 & 37 & 30 & 37 & 30 & 37 \\
\hline $\begin{array}{c}\text { CPAR2_109520 } \\
(C p T U P 1)\end{array}$ & & & & & & & & & & & & & & & & & & \\
\hline CPAR2_200040 OE & & & & & & & & & & & & & & & & & & \\
\hline $\begin{array}{l}\text { CPAR2_302400 } \\
(C p M G T 1)\end{array}$ & & & & & & & & & & & & & & & & & & \\
\hline
\end{tabular}

To evaluate the spot assay experiment, the following categories were assessed to compare the growth of the mutants to that of the wild type: No growth (in contrast to the wild type, the mutant did not form any colonies); strong defect (reduced growth was seen in the $10^{4}-10^{5}$ spots, and there was usually no growth at lower cell concentrations); medium defect (reduced growth capacity was observed with the $10^{3}-10^{4}$ spots, the $10^{5}$ spot showed normal growth, and, usually, the $10^{2}$ had no growth); slight defect (reduced growth capacity was observable at $10^{2}-10^{3}$ spots, and, usually, the $10^{4}-10^{5}$ spots showed normal growth); no difference (the viability of the mutant was indistinguishable from that of the control).

The fitness of the CPAR2_302400 ${ }^{\mathrm{OE}}$ strain decreased upon exposure to each of the cell wall-and membrane perturbing agents tested (Figure 1). The viability of this strain in the presence of CR or CFW was reduced in a concentration-dependent manner. Increasing concentration of CR resulted in medium $(10,25,50,75 \mu \mathrm{g} / \mathrm{mL})$ to strong $(75$ and $100 \mu \mathrm{g} / \mathrm{mL})$ growth defect. No growth or strong growth defect was observed when CFW was applied in a concentration of $50 \mu \mathrm{g} / \mathrm{mL}$, while no defect was found at lower stressor concentrations. CPAR2_302400 ${ }^{\mathrm{OE}}$ was the only mutant that showed a growth defect in the presence of caffeine. A strong growth defect was observed when the cells were incubated in the presence of the membrane perturbing agent SDS.

Slight, medium, or strong reductions in fitness were observed when cells were exposed to CR or CFW agents during the investigation of the CPAR2_200040 ${ }^{\mathrm{OE}}$ mutant (Figure 1).

The CPAR2_109520 ${ }^{\mathrm{OE}}$ showed a medium growth defect only in the presence of SDS (Figure 1).

\subsubsection{The Examined OE Mutants Did Not Display Any Alterations in Morphology or} Pseudohypha Formation

In contrast with C. albicans, C. parapsilosis is unable to form true hypha, although it is able to produce pseudohypha. The capability of reversible switching between yeast and filamentous form is an important virulence factor as it can enhance yeast surface/size and facilitate adhesion. Adhesion can lead to biofilm formation and colonization, which contribute to the intrusion of the fungus into the host cells and subsequent dissemination inside the host. It can also play a protective role for the fungus against the host immune cells and can be a tool to avoid phagocytosis [58]. Genetic elements responsible for dimorphic transition have been explored in C. albicans by gene deletion or expression analysis, and there have been further attempts to reveal morphological and filamentation regulatory 
functions in other Candida species [59-63]. Studies have concluded that the filamentary regulation pathways revealed in C. albicans are partially (evolutionary) conserved compared to other Candida species (C. parapsilosis, C. tropicalis, C. guilliermondii, C. dubliniensis) [61,64].

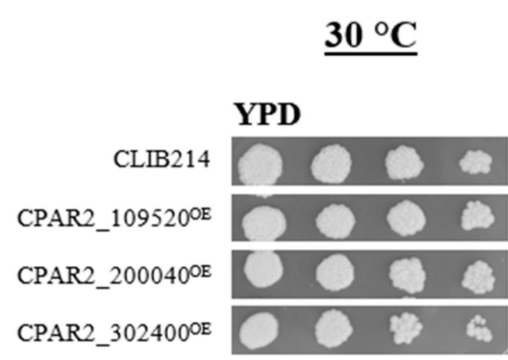

CFW $25 \mu \mathrm{g} / \mathrm{mL}$

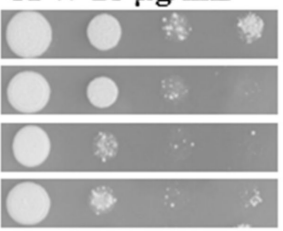

CR $10 \mu \mathrm{g} / \mathrm{mL}$
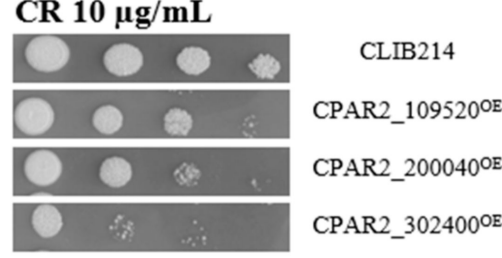

CR $50 \mu \mathrm{g} / \mathrm{mL}$

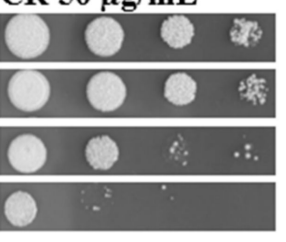

CR $100 \mu \mathrm{g} / \mathrm{mL}$
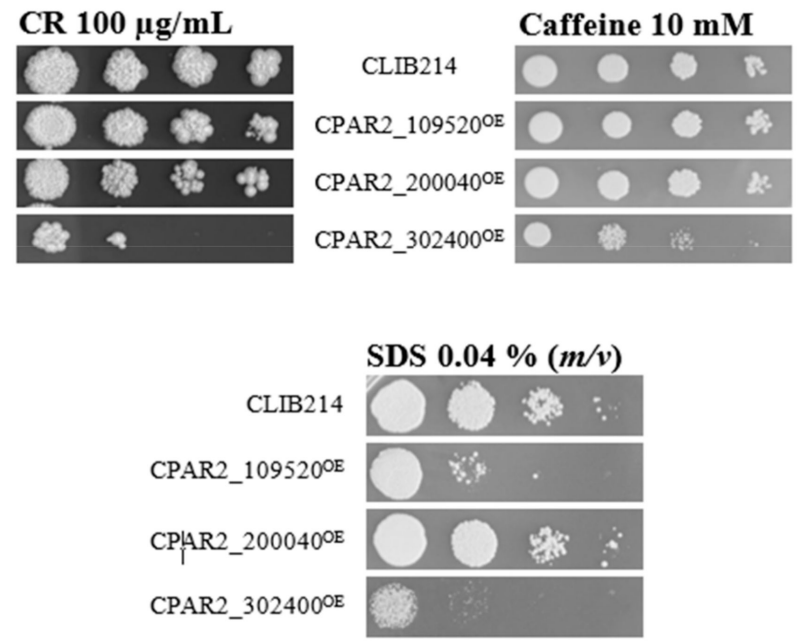

$\underline{37^{\circ} \mathrm{C}}$

YPD

CLIB214

CPAR2_1095200E

CPAR2_200040 OE

CPAR2_302400

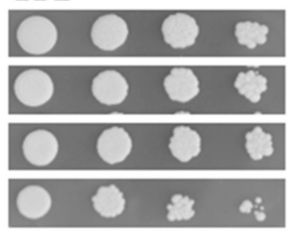

CFW $25 \mu \mathrm{g} / \mathrm{mL}$

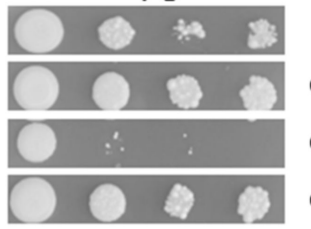

CLIB214
CPAR2_109520
PAR2_200040
CPAR2_302400
OE

CFW $50 \mu \mathrm{g} / \mathrm{mL}$

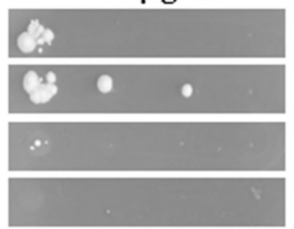

CR $10 \mu \mathrm{g} / \mathrm{mL}$
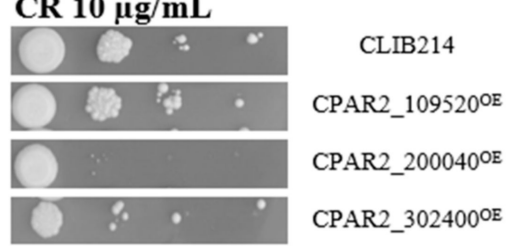

CR $50 \mu \mathrm{g} / \mathrm{mL}$

CR $100 \mu \mathrm{g} / \mathrm{mL}$

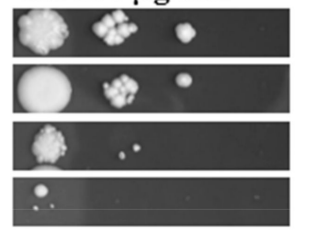

CLIB214

CPAR2_109520 0 E

CPAR2_200040

CPAR2_302400 0 E

\section{Caffeine $10 \mathrm{mM}$}

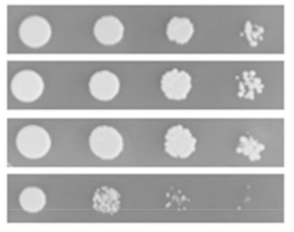

Figure 1. Representative pictures present CPAR2_109520 ${ }^{\mathrm{OE}}, \mathrm{CPAR} 2$ 200040 $\mathrm{OE}$, and CPAR2_302400 ${ }^{\mathrm{OE}}$ strains with altered fitness compared to CLIB214 control strain in spot assay analysis. Tenfold dilutions of the cell suspensions ranging from $10^{5}$ cell $/ 5 \mu \mathrm{L}$ to $10^{2}$ cell $/ 5 \mu \mathrm{L}$ were pinned onto the surface of the solid media and kept for $48 \mathrm{~h}$ at 30 or $37^{\circ} \mathrm{C}$. Except for CFW $(50 \mu \mathrm{g} / \mathrm{mL})$ and CR $(50,100 \mu \mathrm{g} / \mathrm{mL})$ at $37^{\circ} \mathrm{C}$, that was incubated for $3-4$ days.

The screen of the OE strain collection for potential alterations in pseudophypha formation in two different liquid media at $37^{\circ} \mathrm{C}$ and $5 \%(v / v) \mathrm{CO}_{2}$ using a light microscope (qualitative analysis) as well as the Amnis ${ }^{\circledR}$ FlowSight ${ }^{\circledR}$ flow cytometer (quantitative analysis) revealed no detectable alterations in the mutants' capacity to form pseudohypha (Table S4 and Figure S7). 


\subsubsection{Overexpression of the CPAR2_302400 Gene Resulted in Attenuated Biofilm Formation}

Adherence and morphology switching can facilitate or strengthen biofilm formation and the virulence of a pathogenic fungal species, and C. parapsilosis forms biofilms on the surfaces of various medical devices, enabling nosocomial systemic infections [65]. Holland et al. examined C. albicans and C. parapsilosis biofilm-associated genes and concluded that different factors are responsible for biofilm development in these two species. While CZF1, UME6, CPH2, and GZF3 are the major regulators for C. parapsilosis biofilm formation, in C. albicans BRG1 and TEC1 were found to be the central regulators of this process $[28,66]$. Building on the data gained from C. parapsilosis transcriptome and $\mathrm{KO}$ collection analyses, we aimed to utilize the complementary OE strategy to investigate this attribute of the fungus under biofilm-inducing conditions by monitoring their metabolic activity. We found that only CPAR2_302400 ${ }^{\mathrm{OE}}$ showed attenuated biofilm formation compared to the control strain (Figure 2 and Figure S8).

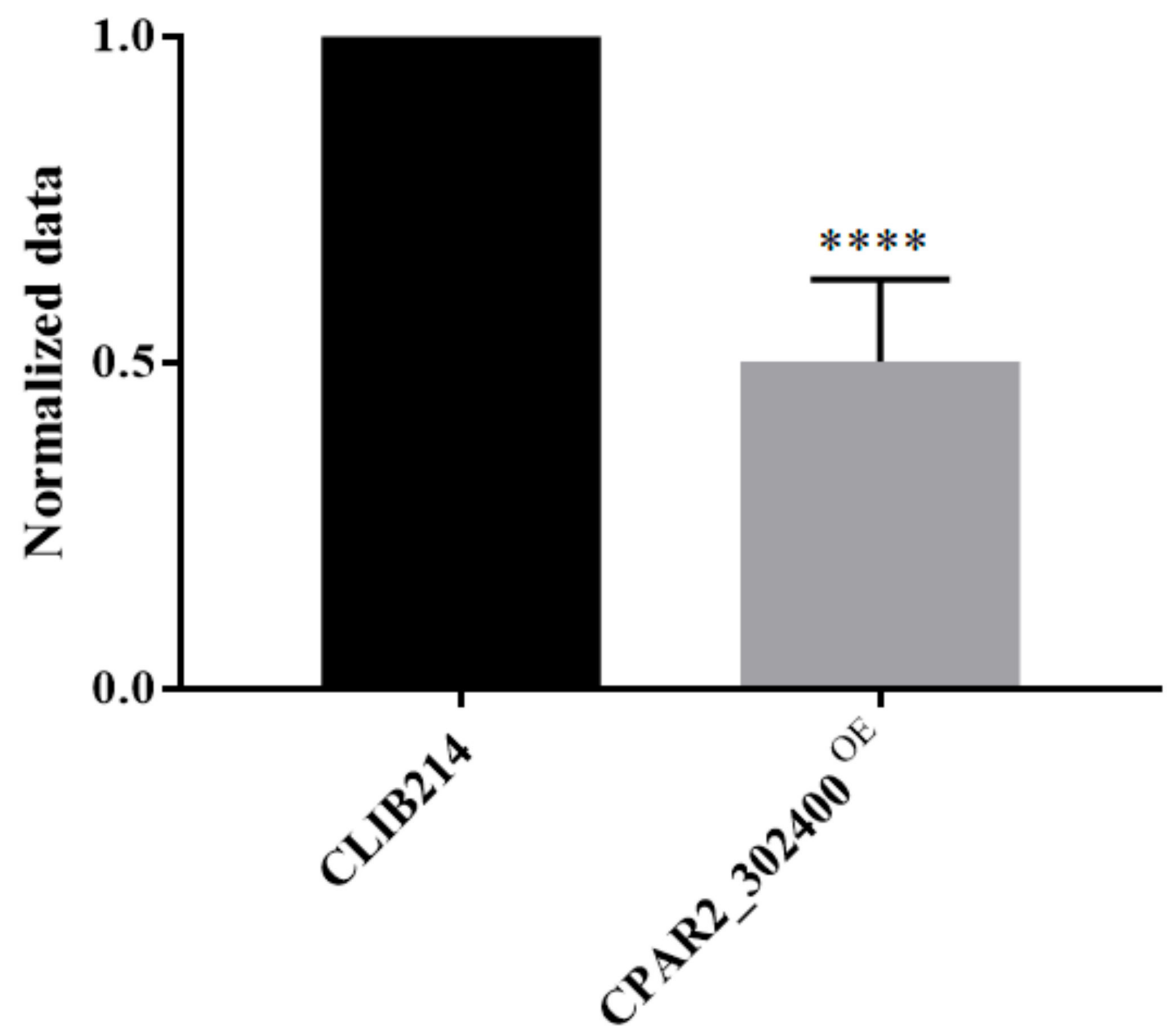

Figure 2. Biofilm formation analysis. $\mathrm{OD}_{540}$ values of the overexpression $(\mathrm{OE})$ strains were normalized to the CLIB214 control strain, $n=3$ with eight parallel samples per experiment. Statistical analysis: one-way ANOVA, Dunnett's multiple comparisons test $\left.{ }^{* * * *} p<0.0001\right)$.

\subsubsection{Overexpression of Selected Genes Did Not Affect Tolerance to Echinocandins}

Echinocandins represent the primary therapy to treat candidaemia in clinical practice; however, C. parapsilosis isolates show higher tolerance to these drugs compared to other Candida species $[2,17,67]$. A possible explanation for this is that $C$. parapsilosis isolates tend to accumulate point mutations in the hot spot region of antifungal resistance-related genes, causing a gain-of-function phenotype leading to increases in the tolerance to echinocandins [16]. To test how the overexpression of the selected genes affects the susceptibility of the mutants to echinocandins, the MICs of each of the strains to the three major members of this class of drugs were determined. The OE mutants displayed similar MICs to those of the control strains independently of whether anidulafungin (ANF), caspofungin (CAF), or micafungin (MIF) was applied. After $48 \mathrm{~h}$ of incubation, the $\mathrm{MIC}_{\mathrm{ANF}}$ values of the mutants and the $C$. parapsilosis control strains were $2-4 \mu \mathrm{g} / \mathrm{mL}$, both $\mathrm{MIC}_{\mathrm{CAF}}$ and $\mathrm{MIC}_{\mathrm{MIF}}$ values 
were 1-2 $\mu \mathrm{g} / \mathrm{mL}$, while higher sensitivity was recorded in the case of $C$. krusei $\left(\mathrm{MIC}_{\mathrm{ANF}}\right.$ : $0.125-0.25 \mu \mathrm{g} / \mathrm{mL}$; $\mathrm{MIC}_{\mathrm{CAF}}: 0.5 \mu \mathrm{g} / \mathrm{mL} ; \mathrm{MIC}_{\mathrm{MIF}}: 0.25 \mu \mathrm{g} / \mathrm{mL}$ ). These results are in line with the literature $[68,69]$ (Table S5).

3.2.6. Overexpression of Certain Genes Interferes with Resistance to Phagocytosis by J774.2 Cells

Phagocytes represent the primary cellular components of the innate immune system to fight against Candida cells reaching the tissues. Macrophages are among the first line of cellular responders that combat fungal invasion by rapidly infiltrating to the site of the infection, where they attempt to ingest and eliminate yeast cells. However, successful fungal pathogens have evolved specific mechanisms through which they are capable of interfering with macrophage responses, and some can even survive within macrophages, indicating that the capability of an intruding pathogen to avoid endocytosis and lysis by the host immune system is an important virulence trait [70-73]. To investigate if the $\mathrm{OE}$ strains had altered interactions with host phagocytic cells, we fluorescently labeled the $\mathrm{OE}$ strains with Alexa Fluor ${ }^{\mathrm{TM}} 488$ succinimidyl ester dye (Invitrogen) and co-cultured them with J774.2 murine macrophage-like cells in vitro. We monitored the phagocytic efficiency after $1 \mathrm{~h}$ using Amnis ${ }^{\circledR}$ FlowSight $^{\circledR}$ flow cytometer by determining the percentages of the phagocytic activity of each sample and normalized to CLIB214 control values. We identified three strains (CPAR2_108840 ${ }^{\mathrm{OE}}, \mathrm{CPAR2} 109520^{\mathrm{OE}}, \mathrm{CPAR} 2200040^{\mathrm{OE}}$ ) that were more efficiently phagocytosed and two strains (CPAR2_406400 ${ }^{\mathrm{OE}}, \mathrm{CPAR} 2500180^{\mathrm{OE}}$ ) that were less effectively phagocytosed by murine macrophages (Figure 3).

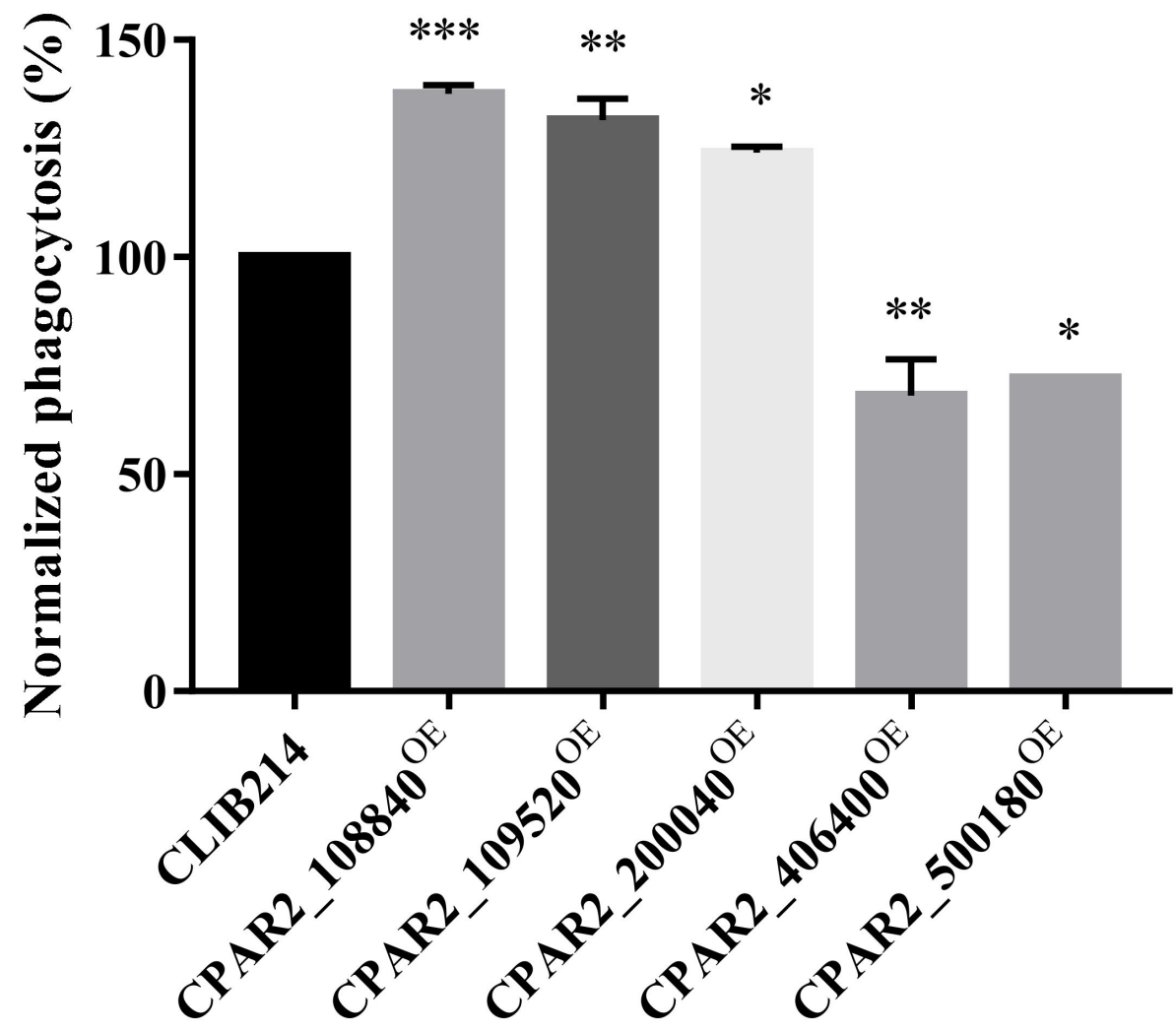

Figure 3. J774 phagocytosis analysis. Phagocytic activity (\%) of the J774 macrophages during the co-incubation with OE strains were normalized to the values of the phagocytosed CLIB214 control strain, $n=3$. Statistical analysis: one-way Anova, Dunnett's multiple comparisons test ${ }^{*} p \leq 0.05$; ** $p \leq 0.01 ; * * * 0.001)$. 
3.2.7. Overexpression of Certain Genes Regulate Virulence Related Processes in Galleria mellonella Larvae Model

Galleria mellonella larvae possess similar humoral and cellular innate immune mechanisms as mammalian hosts; therefore, this insect is widely used as a substitute model for vertebrate infection experiments in order to reduce mammalian consumption. To reveal if the overexpression of the selected genes had an effect on the virulence of C. parapsilosis in this model, G. mellonella larvae were infected with the OE strains, and their survival was monitored. Shortly after the injection, the larvae became brownish due to a process called melanization. This is a common and rapid reaction of insects against any kind of foreign particles (including pathogens), whereby the hemocytes surround the foreign particle and start producing melanin via a multistep biochemical process [74]. In the case of $G$. mellonella, the melanization occurs within minutes after injection with $C$. parapsilosis. Melanization failed to occur following infection with CPAR2_302400 OE , but there were similar survival rates to that of the control strain. However, we identified three melanininducing strains (CPAR2_107240 ${ }^{\mathrm{OE}}, \mathrm{CPAR} 2 \_109520^{\mathrm{OE}}$, and CPAR2_602820 ${ }^{\mathrm{OE}}$ ) that were more virulent compared to the control strain (Figure 4)

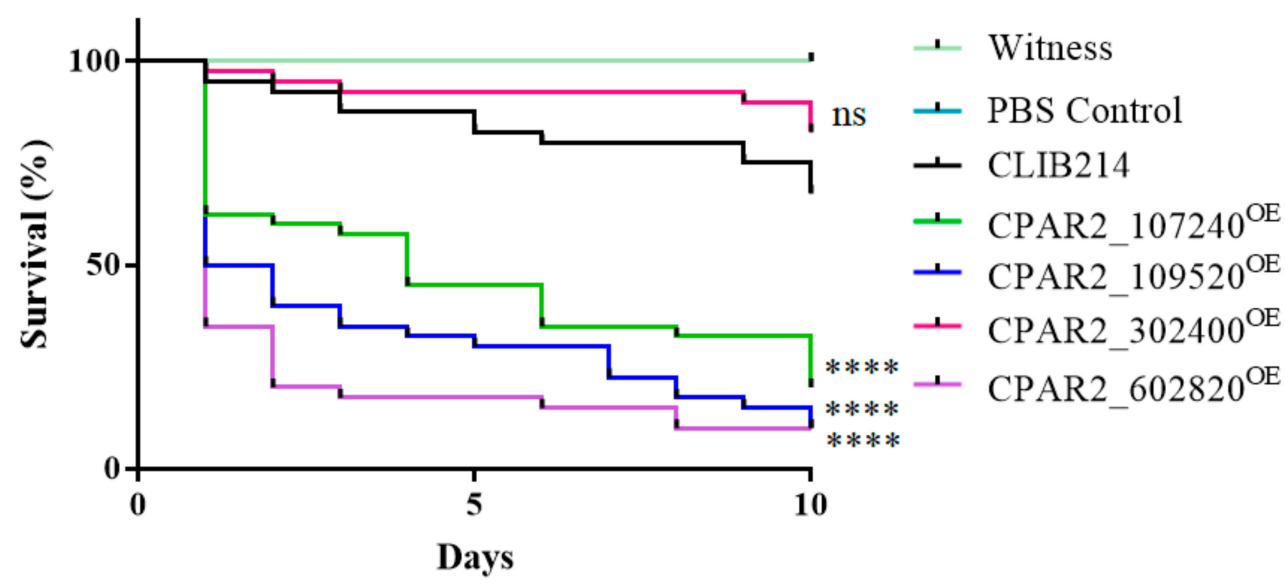

Figure 4. Summarized results of the in vivo Galleria. mellonella infection experiments, $n=3$, separate experiments with 20 larvae per strain and experiment. Statistical analysis: Log-rank (Mantel-Cox) test ${ }^{* * * *} p<0.0001 ; \mathrm{ns}$ is not significant).

3.2.8. Overexpression of the Selected Genes Does Not Affect Certain Components of the Cell Wall

Based on the results of the aforementioned experiments, certain components of the cell wall (chitin and its oligomer compounds and alpha mannan content) were further examined using specific cell wall stains. We found that none of the examined mutant strains showed an alteration compared to the control strains, neither in the distribution nor in the amount of the examined elements of the cell wall (Figure S9).

\subsubsection{CPAR2_109520 and CPAR2_302400 Differentially Alter Fungal Burden in Organs} within Mus Musculus

We next examined the virulence of two OE mutant strains in a mouse infection model, which represents the "gold" standard of in vivo infection models. We selected CPAR2_109520 ${ }^{\mathrm{OE}}$ because it was more virulent than the control strain in the G. melonella model. We also chose CPAR2_302400 ${ }^{\mathrm{OE}}$, which was not significantly different from the wild type in terms of the survival of G. mellonella, but it did not induce melanization in the larvae. In the case of CPAR2_302400 ${ }^{\mathrm{OE}}$, we detected elevated fungal burdens in the brain and kidney tissues, while there were lower CFUs in the spleens and livers. CPAR2_109520 OE also had higher CFU levels in brain samples, while there was a reduced splenic fungal burden (Figure 5). 

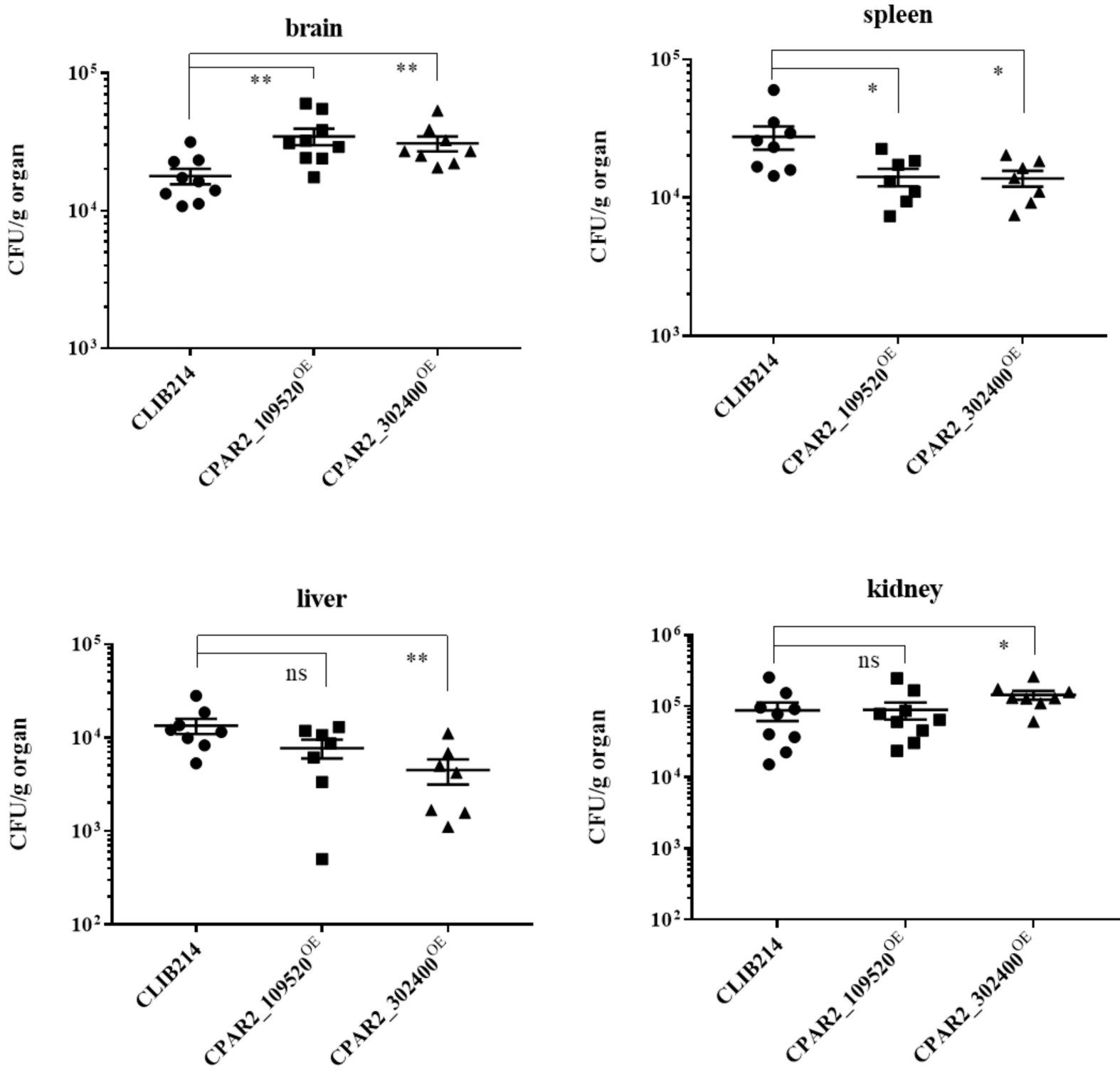

Figure 5. Murine infection experiments. The graphs show the fungal burden (CFU values) of brain, spleen, liver, and kidney in CFU/g organ values. Animals were infected with $2 \times 10^{7}$ fungal cells through their lateral tail veins and sacrificed after 3 days, $n=2$ separate experiments, with four to five animals per strain and experiment were used. For the statistical analysis Mann-Whitney tests were used $\left({ }^{*} p<0.05 ;{ }^{* *} p<0.01\right.$; ns: not significant).

\section{Discussion}

The aim of this study was to generate and rigorously examine an OE mutant strain collection with the purpose of identifying virulence factors in C. parapsilosis. We investigated stress tolerance, morphology switch, biofilm-forming capacity, phagocytosis, and in vivo virulence in G. mellonella larvae and BALB/c mice. During our examinations, we found eight OE mutants with altered phenotype compared to the applied control strains. Both the CPAR2_109520 ${ }^{\mathrm{OE}}$ and CPAR2_302400 ${ }^{\mathrm{OE}}$ mutants showed an altered phenotype under three conditions, the CPAR2_200040 ${ }^{\mathrm{OE}}$ strain under two conditions, while the other five mutant strains under a single condition compared to the control strains (Figure 6, Table S6). In addition, the CPAR2_109520 ${ }^{\mathrm{OE}}$ and CPAR2_302400 ${ }^{\mathrm{OE}}$ mutants were selected for murine experiments, and alterations in CFU values in different tissues were found relative to the wild type control strain. During the investigation of morphology, pseudohypha formation, and antifungal susceptibility, we detected no alterations in the OE strains compared to controls (Figure 6). 


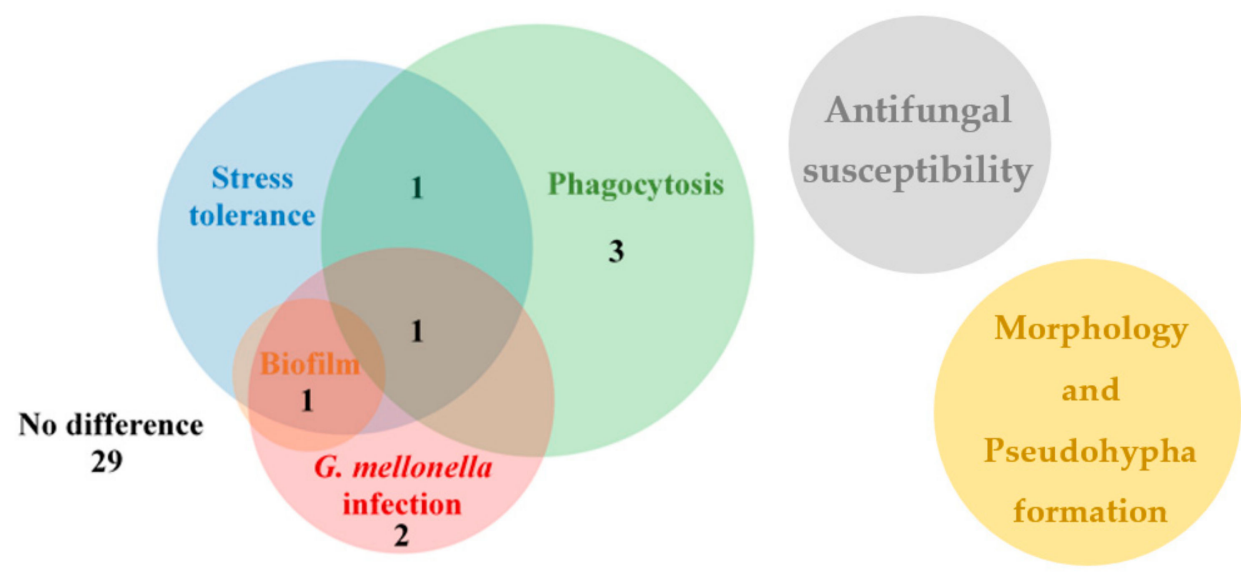

Figure 6. The Venn diagram shows summarized results of the OE mutant collection analysis separated into distinct experiments. The numbers display the number of mutant strains with alteration(s) in the exact experiment(s).

Recently, the function of three of the examined 37 genes was determined by Cillingova and co-workers [19]. The CPAR2_100460 (CpHBT4), the CPAR2_100470 (CpHBT3), and the CPAR2_204840 (CpHBT2) genes were confirmed as hydroxybenzoate transporters. The investigators reported that the $C P H B T 4$ deletion mutant showed resistance to caffeine and altered sensitivity to caspofungin and fluconazole; however, we found no alteration under any tested conditions in the case of the OE parallel mutant strains. The function of 18 of the 37 genes' orthologs has already been confirmed in S. cerevisiae, while 15 orthologs functions have been examined in C. albicans [25]. Notably, CPAR2_200040 has no confirmed functional ortholog in either of these other yeast species.

In order to further evaluate the results, we compared the data from the OE collection analysis to the results derived from previous $\mathrm{KO}$ mutant library characterizations. According to Prelich, during comparison of the $\mathrm{KO}$ and the OE phenotype of the same gene, three phenomena can be observed: opposite (hypermorph or hypomorph) phenotypes $(-/+$; $+/-)$; similar phenotypes $(-/-;+/+; 0 / 0)$; no phenotype versus altered (neomorph or antimorph) properties $(-/ 0$ or $0 /-;+/ 0$ or $0 /+)$ [36]. Amongst the studied OE mutant strains here, there are 12 [29], four [28], and three [19] (18 different genes in total) KOs available in C. parapsilosis that were characterized with similar methods, and importantly, they have common genetic background enabling proper comparison of the mutant pairs (Table S3).

The ortholog gene to CPAR2_109520 encodes a transcriptional corepressor protein, CaTUP1, which represses filamentous growth [75]. The CPAR2_109520 ${ }^{\mathrm{OE}}$ mutant displayed alterations in stress tolerance, phagocytosis, and both in vivo experiments. This OE mutant showed a medium growth defect only in the presence of SDS at 30 and $37^{\circ} \mathrm{C}$ and was more avidly endocytosed by macrophages. A similar reduction in growth was also observed in a C. parapsilosis deletion mutant of the gene in question (with additional sensitivity to other conditions as well) [28]. The C. albicans TUP1 null mutant showed abnormal colony morphology and increased filamentous growth compared to its originating strain [75-78]. A previous study also examining virulence in a C. albicans TUP1 KO found reductions in adhesion, invasion, and damage with oral epithelial cells [79]. Although we also recorded reduced virulence properties of the CPAR2_ $109520^{\mathrm{OE}}$ mutant in in vitro experiments, we found this mutant to be more virulent than the wild type $C$. parapsilosis control strain in G. mellonella model.

The putative ortholog of the CPAR2_302400 gene functions as a DNA repair methyltransferase (ScMGT1) in S. cerevisiae $[80,81]$. The null mutant of this gene in S. cerevisiae showed increased growth in competitive fitness analysis [30], but there was no significant alteration in a biofilm assay [82]. A C. albicans null mutant also displayed normal phenotype in fitness analysis [27]; however, a C. parapsilosis $\mathrm{KO}$ showed decreased adhesive 
properties, but there was not any difference in its biofilm-forming capacity compared to the control strain [83]. In the current study, the G. mellonella model confirmed the importance of melanization against invading pathogens. The only OE strain that was coupled with the absence of melanization was CPAR2_302400 $\mathrm{OE}$, which produced a survival curve similar to that of the control strain. Although we could not detect any alteration in phagocytosis efficiency, the mutant showed severe growth defects in other important virulence properties such as stress tolerance or biofilm formation. The fitness of the CPAR2_302400 $\mathrm{OE}$ strain decreased upon exposure to each of the cell wall and membrane perturbing agents (CFW, CR, SDS, and caffeine). This mutant was the only one out of the 37 tested whose growth was reduced in the presence of caffeine and the only one that showed decreased biofilm production. Biofilm formation enables invasion while concomitantly providing protection of the pathogen from different antifungal agents and helps avoid recognition by host immune cells. C. parapsilosis is able to form biofilm on the surfaces of various medically used devices, thus it is a notable virulence factor [65]. This is the first report to connect the CPAR2_302400 gene function to the biofilm regulatory network of $C$. parapsilosis, and thus to the pathogenicity of this species.

To further investigate the virulence properties of the strains, we selected two OE strains for study in a mammalian model. We chose a strain with increased virulence in the larval model, CPAR2_109520 $\mathrm{OE}$, and one that did not induce larval melanization but had virulence similar to the control strain, CPAR2_302400 ${ }^{\mathrm{OE}}$. The G. mellonella larvae and murine data suggest different invasion efficiencies of the mutants in diverse tissues or various mechanism or capacity of fungi depletion in the examined organs. Significantly higher fungal burdens were enumerated in the brains of mice infected with the CPAR2_109520 OE mutant, while lower CFU numbers were observed in the spleen. For CPAR2_302400 OE, which was similar to wild type control yeast in G. mellonella, significantly higher CFUs were found in both the brains and kidneys of challenged mice, while lower counts were enumerated in the spleens and livers. Other comparative studies examining the correlation between the results derived from the wax moth and murine infections have also shown discordant results [84-86]. Nevertheless, monitoring survival in mice is not optimal in the case of many NAC species like C. parapsilosis, since they do not cause lethal infections in this species, while lethality can be measured in insect models [87]. Interestingly, in a mouse systemic infection model, the C. albicans TUP1 (CPAR2_109520 gene's ortholog) null mutant, showed decreased virulence [78], whereas another study reported no mortality 30 days after i.v. infection with the same mutant [88]. Further, C. albicans MGT1 (the ortholog of CPAR2_302400) null mutant displayed no altered phenotype in competitive experiments during i.v. infection in mice [27]. These findings underscore the imperative to explore pathogenesis studies in individual Candida species as determinations made with C. albicans cannot routinely be extrapolated to have similar behaviors in these biologically different pathogens.

The CPAR2_107240 ${ }^{\mathrm{OE}}$ and CPAR2_602820 ${ }^{\mathrm{OE}}$ mutants were also more virulent in G. mellonella experiments. The CaKTR4/MNT4 (CPAR2_107240 gene's ortholog) gene was verified as a mannosyltranferase in $C$. albicans where it has a role in $\mathrm{N}$-linked glycosylation and cell wall regeneration [89]. The null mutant of the gene showed normal growth capacity, morphology, and competitive fitness in pooled mice infection model [27]. Only the double, triple, quadruple, or quintuple deletion of the CaMNT1-2-3-4-5 genes in different combinations (but not the single ones) resulted in mutants with altered cell wall content and elevated sensitivity to cell wall perturbing agents (CFW or SDS), indicating that MNT genes of $C$. albicans have redundant functions [89]. Changes in the composition of the cell wall imply alterations in host-pathogen interactions as well [89]. The CPAR2_602820 ortholog gene ( $C a F C A 1)$ encodes a cytosine deaminase, an enzyme of pyrimidine salvage [90,91]. The $C$. albicans null mutant was resistant to flucytosine [92]. However, there has been no information about the ortholog genes in connection with host-pathogen interactions in C. parapsilosis. 
The CPAR2_200040 ${ }^{\mathrm{OE}}$ mutant displayed defects in stress tolerance and phagocytosis compared to control strains. The mutant showed slight, medium or strong reduction in fitness in the presence of CR and CFW and displayed elevated uptake by murine macrophages. The function of this gene ortholog's function is unknown. Interestingly, the corresponding $\mathrm{KO}$ mutant of this strain was resistant to CFW compared to the control strain, further confirming the role of CPAR2_200040 in cell wall assembly regulation of C. parapsilosis [29].

The CPAR2_108840 ${ }^{\mathrm{OE}}, \mathrm{CPAR} 24406400^{\mathrm{OE}}$, and the CPAR2_500180 ${ }^{\mathrm{OE}}$ mutants showed altered phenotypes only in the context of phagocytosis experiments. The CPAR2_108840 $\mathrm{OE}$ mutant was more efficiently phagocytosed by macrophages. The function of ScSPS1 (CPAR2_108840 gene's ortholog) is putatively a serine/threonine kinase, which is involved in spore packaging in S. cerevisiae [93]. Its KO parallel was sensitive to SDS in C. parapsilosis [29], while it displayed a normal phenotype in C. albicans [27]. However, the gene has not previously been linked to virulence. We also recorded lower phagocytic events with the CPAR2_406400 ${ }^{\mathrm{OE}}$ mutant strain. The ortholog gene, ScRPA12, was identified in S. cerevisiae as an RNA polymerase I subunit [94]. Chaillot and colleagues found that this gene has a role in cell size homeostasis in C. albicans [95], but it has not been associated with virulence regulation. The CPAR2_500180 ${ }^{\mathrm{OE}}$ mutant displayed a more virulent phenotype in phagocytosis experiments compared to the control strain. Its gene ortholog is ScKIN3, which encodes a nonessential serine/threonine protein kinase that has a possible role in DNA damage responses [96-98]. Its KO parallel was susceptible to Congo red and caffeine in C. parapsilosis [29] and showed increased cell size and decreased resistance to caspofungin in C. albicans $[99,100]$. In S. cerevisiae, its overexpression caused a reduction in vegetative growth, abnormal cellular morphology, and cell cycle [45]; however, we did not observe any of the aforementioned effects. According to the phagocytosis experiments in this study, we monitored alterations occurring at the phases of recognition and uptake. Both recognition and endocytosis primarily depend on the recognition of specific cell wall components of the pathogen. Fungal evasion of recognition occurs via masking these structures or changing morphology type by the fungi [70]. Our results suggest that differences in cell wall composition of these OE mutant strains cause the observed altered phagocytic efficiencies.

During the $\mathrm{OE}$ and $\mathrm{KO}$ phenotype comparisons, we found variations in phenotypes in the case of CPAR2_200040 ${ }^{\mathrm{OE}}$ when we examined CFW tolerance and in vitro host-pathogen interactions [29]. Similar phenotypes were observed with two OE mutants and their KO counterparts. The C. parapsilosis KO pair of the examined CPAR2_109520 ${ }^{\mathrm{OE}}$ mutant was sensitive to SDS. In addition to this, the CPAR2_302400 ${ }^{\mathrm{OE}}$ mutant strain showed decreased adhesive properties, although there was no difference in its biofilm-forming capacity compared to the control strain, while the OE mutant displayed less biofilm formation [29]. We also found absences of phenotypic alterations in $\mathrm{OE}, \mathrm{KO}$, or both parallel mutants based on the literature. The CPAR2_108840 deletion mutant was resistant to SDS, while we did not notice such alterations in the OE strain [29]. Neither the CPAR2_500180 ${ }^{\mathrm{OE}}$ mutant nor its $\mathrm{KO}$ pair displayed any alterations under similar experimental conditions [29]. For the CPAR2_602820 ${ }^{\mathrm{OE}}$ mutant, we found no changes in its fitness during the spot assay analysis, while its deletion strain showed mild and strong defects in growth on minimal media at 30 and $37^{\circ} \mathrm{C}$ (Table S6). When only S. cerevisiae or C. albicans mutant collection analysis data were available, comparisons were more challenging. Additionally, it was necessary to consider whether the overexpressed genes were not unique or correctly manifest when a lack of gain-of-function or no reversed phenotype was observed [36]. In several cases, the $\mathrm{OE}$ and the $\mathrm{KO}$ phenotypes of a given gene did not complement each other. In addition to this, the applied control strains could influence the interpretation of the results. Therefore, in approaching this task, we also assessed the use of the reintegrated $\mathrm{CPRI}$ and an overexpressing strain mCherry ${ }^{\mathrm{OE}}$ as controls in addition to the wild type CLIB214 in fitness-related experiments. We found that it was more appropriate to apply the neutral gene carrier $\mathrm{OE}$ strain $\mathrm{mCherry}{ }^{\mathrm{OE}}$, rather than a mutant bearing an empty 
cassette as a control in order to exclude any alteration in fitness derived from the integration and/or the continuous operation of the expression cassette itself (due to the presence of a constitutive promoter) $[42,46,53]$. As we found no alteration between the three control strains that we examined in preliminary investigations, we selected CLIB214 wild type as the control for subsequent experiments.

Although we examined diverse effects in our OE collection, several important additional areas remain to be explored if genes are examined in a targeted manner using gene deletion or overexpression strategies. These include the (1) gene dosage effect, (2) information about their interactions with other genes and (3) the subsequent transcriptomic effects, (4) off-target mutations, (5) universal behavior in various strains, and (6) the RNA level of an overexpressed gene (what we can measure) does not necessarily correlate with that of the protein it encodes $[36,45,101-103]$. Similar to our findings, previous studies in C. albicans did not find any OE mutants with increased fitness [42,46]. Notably, there is a substantial energy cost to a cell when a gene is duplicated or artificially overexpressed. According to Wagner, increasing protein synthesis above $10 \%$ negatively affects the health of the cell [104]. The function of the query gene also can determine the resulting phenotype, for example, periodically changing genes like cell cycle control genes [45]. So, the detected phenotype depends on the genuine function of the targeted gene. Nevertheless, our work clearly indicates that the application of the OE approach is an effective starting point to explore gene functions, especially when a prescreen (RNAseq data or known function of orthologs) for selected genes is possible. Rapid systematic analysis of the OE mutant collection (including stressors, biofilm formation, in vitro and in vivo infection models) can identify previously unknown virulence-associated genes, which can be analyzed further to reveal gene-specific functions.

In summary, this study was the first attempt to use an OE strategy to comprehensively examine gene function in C. parapsilosis. Significantly, the findings clearly associate CPAR2_107240,CPAR2_406400, and CPAR2_602820 with the virulence of C. parapsilosis. Our results show that $\mathrm{OE}$ approaches are a relevant method for gene function analysis in this lethal, emerging fungus and that $\mathrm{OE}$ methods can define new virulence pathways in C. parapsilosis.

Supplementary Materials: The following are available online at https://www.mdpi.com/2309 $-608 X / 7 / 2 / 97 / s 1$, Figure S1: The schematic figure of the OE vector. Figure S2: Representative figures of the methods for verification of the generated OE mutant strains. Figure S3: Results of the growth kinetic measurements in complete media (YPD). Figure S4: Results of the growth kinetic measurements in minimal media (YNB $+0.5 \%(\mathrm{~m} / \mathrm{v})$ glucose). Figure S5: Results of the growth analyses on solid minimal media and with additional serum. Figure S6: Results of the growth analyses of the 3 control strains on solid media supplemented with different stress agents. Figure S7: Representative figures from pseudohypha analysis by Amnis ${ }^{\circledR}$ FlowSight ${ }^{\circledR}$ flow cytometer. Figure S8: Biofilm forming capacity of the overexpression mutants. Figure S9: Cell wall component analysis of the selected mutants. Table S1: Strains and primers used in this study. Table S2: Applied stressors and their concentrations in solid YPD media for spot assay analysis. Table S3: The list of the selected genes for OE analysis. Table S4: The results of pseudohypha formation experiments. Table S5: The results of the antifungal susceptibility analysis. Table S6: The summarized results of the OE mutant collection analysis.

Author Contributions: Conceptualization, A.G., T.N.; methodology, T.N., S.E.P.; software, S.E.P.; validation, T.N., S.E.P.; formal analysis, T.N., S.E.P.; investigation, T.N., S.E.P.; resources, A.G., C.V.; data curation, T.N., S.E.P., R.T., and J.D.N.; writing-original draft preparation, S.E.P.; writingreview and editing, T.N., R.T., A.G., and J.D.N.; visualization, S.E.P.; supervision, T.N., A.G., C.V.; project administration, T.N., A.G.; funding acquisition, A.G. All authors have read and agreed to the published version of the manuscript.

Funding: This work was supported by grants 20391-3/2018/FEKUSTRAT, NKFIH K 123952, and GINOP-2.3.2.-15-2016-00035. S.E.P. was funded by Richter Gedeon Talentum Foundation. A.G. was further funded by LP2018-15/2018. T.N. was supported by the Postdoctoral Fellowship Programme of the Hungarian Academy of Sciences. 
Institutional Review Board Statement: The study was conducted according to the guidelines of the Declaration of Helsinki, and approved by the Institutional Review Board of University of Szeged (protocol code XVI./3652/2016, date of approval: 05. 10. 2016).

Informed Consent Statement: Not applicable.

Data Availability Statement: The data presented in this study are available in "A Candida parapsilosis Overexpression Collection Reveals Genes Required for Pathogenesis".

Acknowledgments: We wish to thank Katalin Csonka for the help with mouse experiments and Erik Zajta and Csaba Papp for the assistant in flow cytometry analysis. We are grateful to Geraldine Butler for kindly providing CLIB214, CPL2, CPRI fungal strains. We are thankful to Christophe d'Enfert for the vector $\mathrm{PCA}-\mathrm{DEST} 1300$.

Conflicts of Interest: The authors declare no conflict of interest.

\section{References}

1. Warnock, D.W. Trends in the epidemiology of invasive fungal infections. Nippon Ishinkin Gakkai Zasshi 2007, 48, 1-12. [CrossRef]

2. Pfaller, M.A.; Diekema, D.J. Epidemiology of invasive Candidiasis: A persistent public health problem. Clin. Microbiol. Rev. 2007, 20, 133-163. [CrossRef]

3. Cleveland, A.A.; Farley, M.M.; Harrison, L.H.; Stein, B.; Hollick, R.; Lockhart, S.R.; Magill, S.S.; Derado, G.; Park, B.J.; Chiller, T.M.; et al. Changes in incidence and antifungal drug resistance in Candidemia: Results from population-based laboratory surveillance in Atlanta and Baltimore, 2008-2011. Clin. Infect. Dis. 2012, 55, 1352-1361. [CrossRef]

4. Siopi, M.; Tarpatzi, A.; Kalogeropoulou, E.; Damianidou, S.; Vasilakopoulou, A.; Vourli, S.; Pournaras, S.; Meletiadis, J. Epidemiological trends of fungemia in greece with a focus on Candidemia during the recent financial crisis: A 10-Year survey in a tertiary care academic hospital and review of literature. Antimicrob. Agents Chemother. 2020, 64, e01516-19. [CrossRef]

5. Fridkin, S.K.; Kaufman, D.; Edwards, J.R.; Shetty, S.; Horan, T. Changing incidence of Candida bloodstream infections among NICU patients in the United States: 1995-2004. Pediatrics 2006, 117, 1680-1687. [CrossRef]

6. Juyal, D.; Sharma, M.; Pal, S.; Rathaur, V.K.; Sharma, N. Emergence of non-albicans Candida species in neonatal candidemia. N. Am. J. Med. Sci. 2013, 5, 541-545. [CrossRef]

7. Yapar, N. Epidemiology and risk factors for invasive candidiasis. Ther. Clin. Risk Manag. 2014, 10, 95-105. [CrossRef]

8. White, M.H. Editorial response: The contribution of fluconazole to the changing epidemiology of invasive Candidal infections. Clin. Infect. Dis. 1997, 24, 1129-1130. [CrossRef]

9. Nucci, M.; Marr, K.A. Emerging fungal diseases. Clin. Infect. Dis. Off. Publ. Infect. Dis. Soc. Am. 2005, 41, 521-526. [CrossRef]

10. Cleveland, A.A.; Harrison, L.H.; Farley, M.M.; Hollick, R.; Stein, B.; Chiller, T.M.; Lockhart, S.R.; Park, B.J. Declining incidence of Candidemia and the shifting epidemiology of Candida resistance in two US Metropolitan Areas, 2008-2013: Results from population-based surveillance. PLoS ONE 2015, 10, e0120452. [CrossRef]

11. Papon, N.; Courdavault, V.; Clastre, M.; Bennett, R.J. Emerging and emerged pathogenic Candida species: Beyond the Candida albicans paradigm. PLoS Pathog. 2013, 9, e1003550. [CrossRef] [PubMed]

12. Clark, T.A.; Slavinski, S.A.; Morgan, J.; Lott, T.; Arthington-Skaggs, B.A.; Brandt, M.E.; Webb, R.M.; Currier, M.; Flowers, R.H.; Fridkin, S.K.; et al. Epidemiologic and molecular characterization of an outbreak of Candida parapsilosis bloodstream infections in a community hospital. J. Clin. Microbiol. 2004, 42, 4468-4472. [CrossRef] [PubMed]

13. Kuhn, D.M.; Mikherjee, P.K.; Clark, T.A.; Pujol, C.; Chandra, J.; Hajjeh, R.A.; Warnock, D.W.; Soil, D.R.; Ghannoum, M.A. Candida parapsilosis characterization in an outbreak setting. Emerg. Infect. Dis. 2004, 10, 1074-1081. [CrossRef] [PubMed]

14. Pammi, M.; Holland, L.; Butler, G.; Gacser, A.; Bliss, J.M. Candida parapsilosis is a significant neonatal pathogen: A systematic review and meta-analysis. Pediatr. Infect. Dis. J. 2013, 32, e206-e216. [CrossRef] [PubMed]

15. Harrington, R.; Kindermann, S.L.; Hou, Q.; Taylor, R.J.; Azie, N.; Horn, D.L. Candidemia and invasive candidiasis among hospitalized neonates and pediatric patients. Curr. Med. Res. Opin. 2017, 33, 1803-1812. [CrossRef] [PubMed]

16. Tóth, R.; Nosek, J.; Mora-Montes, H.M.; Gabaldon, T.; Bliss, J.M.; Nosanchuk, J.D.; Turner, S.A.; Butler, G.; Vágvölgyi, C.; Gácser, A.; et al. Candida parapsilosis: From genes to the bedside. Clin. Microbiol. Rev. 2019, 32, e00111-18. [CrossRef]

17. Papp, C.; Kocsis, K.; Tóth, R.; Bodai, L.; Willis, J.R.; Ksiezopolska, E.; Lozoya-Pérez, N.E.; Vágvölgyi, C.; Mora Montes, H.; Gabaldón, T.; et al. Echinocandin-induced microevolution of Candida parapsilosis influences virulence and abiotic stress tolerance. mSphere 2018, 3. [CrossRef]

18. Gácser, A.; Trofa, D.; Schäfer, W.; Nosanchuk, J.D. Targeted gene deletion in Candida parapsilosis demonstrates the role of secreted lipase in virulence. J. Clin. Investig. 2007, 117, 3049-3058. [CrossRef]

19. Cillingová, A.; Zeman, I.; Tóth, R.; Neboháčová, M.; Dunčková, I.; Hölcová, M.; Jakúbková, M.; Gérecová, G.; Pryszcz, L.P.; Tomáška, L'; et al. Eukaryotic transporters for hydroxyderivatives of benzoic acid. Sci. Rep. 2017, 7, 8998. [CrossRef]

20. Zoppo, M.; Di Luca, M.; Franco, M.; Rizzato, C.; Lupetti, A.; Stringaro, A.; De Bernardis, F.; Schaudinn, C.; Barrasa, M.I.; Bottai, D.; et al. CpALS4770 and CpALS4780 contribution to the virulence of Candida parapsilosis. Microbiol. Res. 2020, 231, 126351. [CrossRef] 
21. Butler, G.; Rasmussen, M.D.; Lin, M.F.; Santos, M.A.S.; Sakthikumar, S.; Munro, C.A.; Rheinbay, E.; Grabherr, M.; Forche, A.; Reedy, J.L.; et al. Evolution of pathogenicity and sexual reproduction in eight Candida genomes. Nature 2009, 459, 657-662. [CrossRef] [PubMed]

22. Pryszcz, L.P.; Németh, T.; Gácser, A.; Gabaldón, T. Unexpected genomic variability in clinical and environmental strains of the pathogenic yeast Candida parapsilosis. Genome Biol. Evol. 2013, 5, 2382-2392. [CrossRef] [PubMed]

23. Logue, M.E.; Wong, S.; Wolfe, K.H.; Butler, G. A genome sequence survey shows that the pathogenic yeast Candida parapsilosis has a defective MTLa1 allele at its mating type locus. Eukaryot. Cell 2005, 4, 1009-1017. [CrossRef] [PubMed]

24. Nosek, J.; Holesova, Z.; Kosa, P.; Gacser, A.; Tomaska, L. Biology and genetics of the pathogenic yeast Candida parapsilosis. Curr. Genet. 2009, 55, 497-509. [CrossRef] [PubMed]

25. Candida Parapsilosis CDC317 Genome Snapshot/Overview. Available online: http://www.candidagenome.org/cache/C_ parapsilosis_CDC317_genomeSnapshot.html (accessed on 16 November 2020).

26. Candida albicans SC5314 Genome Snapshot/Overview. Available online: http://www.candidagenome.org/cache/C_albicans_ SC5314_genomeSnapshot.html (accessed on 16 November 2020).

27. Noble, S.M.; French, S.; Kohn, L.A.; Chen, V.; Johnson, A.D. Systematic screens of a Candida albicans homozygous deletion library decouple morphogenetic switching and pathogenicity. Nat. Genet. 2010, 42, 590-598. [CrossRef]

28. Holland, L.M.; Schröder, M.S.; Turner, S.A.; Taff, H.; Andes, D.; Grózer, Z.; Gácser, A.; Ames, L.; Haynes, K.; Higgins, D.G.; et al. Comparative phenotypic analysis of the major fungal pathogens Candida parapsilosis and Candida albicans. PLOS Pathog. 2014, 10, e1004365. [CrossRef] [PubMed]

29. Tóth, R.; Cabral, V.; Thuer, E.; Bohner, F.; Németh, T.; Papp, C.; Nimrichter, L.; Molnár, G.; Vágvölgyi, C.; Gabaldón, T.; et al. Investigation of Candida parapsilosis virulence regulatory factors during host-pathogen interaction. Sci. Rep. 2018, 8, 1346. [CrossRef]

30. Breslow, D.K.; Cameron, D.M.; Collins, S.R.; Schuldiner, M.; Stewart-Ornstein, J.; Newman, H.W.; Braun, S.; Madhani, H.D.; Krogan, N.J.; Weissman, J.S.; et al. A comprehensive strategy enabling high-resolution functional analysis of the yeast genome. Nat. Methods 2008, 5, 711-718. [CrossRef]

31. Verma, R.; Pradhan, D.; Maseet, M.; Singh, H.; Jain, A.K.; Khan, L.A. Genome-wide screening and in silico gene knockout to predict potential candidates for drug designing against Candida albicans. Infect. Genet. Evol. 2020, 80, 104196. [CrossRef]

32. Noble, S.M.; Johnson, A.D. Strains and strategies for large-scale gene deletion studies of the diploid human fungal pathogen Candida albicans. Eukaryot. Cell 2005, 4, 298-309. [CrossRef]

33. Reuss, O.; Vik, A.; Kolter, R.; Morschhäuser, J. The SAT1 flipper, an optimized tool for gene disruption in Candida albicans. Gene 2004, 341, 119-127. [CrossRef]

34. Lombardi, L.; Salzberg, L.I.; Cinnéide, E.Ó.; O’Brien, C.; Butler, G. Large-scale generation of mutant strains in Candida parapsilosis using CRISPR-Cas9. Access Microbiol. 2019, 1, 695. [CrossRef]

35. Vyas, V.K.; Barrasa, M.I.; Fink, G.R. A Candida albicans CRISPR system permits genetic engineering of essential genes and gene families. Sci. Adv. 2015, 1, e1500248. [CrossRef]

36. Prelich, G. Gene overexpression: Uses, mechanisms, and interpretation. Genetics 2012, 190, 841-854. [CrossRef]

37. Rorth, P.; Szabo, K.; Bailey, A.; Laverty, T.; Rehm, J.; Rubin, G.M.; Weigmann, K.; Milan, M.; Benes, V.; Ansorge, W.; et al. Systematic gain-of-function genetics in Drosophila. Development 1998, 125, 1049-1057.

38. Palatnik, J.F.; Allen, E.; Wu, X.; Schommer, C.; Schwab, R.; Carrington, J.C.; Weigel, D. Control of leaf morphogenesis by microRNAs. Nature 2003, 425, 257-263. [CrossRef]

39. Chua, G.; Morris, Q.D.; Sopko, R.; Robinson, M.D.; Ryan, O.; Chan, E.T.; Frey, B.J.; Andrews, B.J.; Boone, C.; Hughes, T.R.; et al. Identifying transcription factor functions and targets by phenotypic activation. Proc. Natl. Acad. Sci. USA 2006, 103, 12045-12050. [CrossRef]

40. Liu, Y.; Kern, J.T.; Walker, J.R.; Johnson, J.A.; Schultz, P.G.; Luesch, H. A genomic screen for activators of the antioxidant response element. Proc. Natl. Acad. Sci. USA 2007, 104, 5205-5210. [CrossRef]

41. Schubert, S.; Barker, K.S.; Znaidi, S.; Schneider, S.; Dierolf, F.; Dunkel, N.; Aïd, M.; Boucher, G.; Rogers, P.D.; Raymond, M.; et al. Regulation of efflux pump expression and drug resistance by the transcription factors Mrr1, Upc2, and Cap1 in Candida albicans. Antimicrob. Agents Chemother. 2011, 55, 2212-2223. [CrossRef]

42. Cabral, V.; Znaidi, S.; Walker, L.A.; Martin-Yken, H.; Dague, E.; Legrand, M.; Lee, K.; Chauvel, M.; Firon, A.; Rossignol, T.; et al. Targeted changes of the cell wall proteome influence Candida albicans ability to form single- and multi-strain biofilms. PLoS Pathog. 2014, 10, e1004542. [CrossRef]

43. Schillig, R.; Morschhäuser, J. Analysis of a fungus-specific transcription factor family, the Candida albicans zinc cluster proteins, by artificial activation. Mol. Microbiol. 2013, 89, 1003-1017. [CrossRef]

44. Schwarzmüller, T.; Ma, B.; Hiller, E.; Istel, F.; Tscherner, M.; Brunke, S.; Ames, L.; Firon, A.; Green, B.; Cabral, V.; et al. Systematic phenotyping of a large-scale Candida glabrata deletion collection reveals novel antifungal tolerance genes. PLoS Pathog. 2014, 10, e1004211. [CrossRef]

45. Sopko, R.; Huang, D.; Preston, N.; Chua, G.; Papp, B.; Kafadar, K.; Snyder, M.; Oliver, S.G.; Cyert, M.; Hughes, T.R.; et al. Mapping pathways and phenotypes by systematic gene overexpression. Mol. Cell 2006, 21, 319-330. [CrossRef] 
46. Znaidi, S.; van Wijlick, L.; Hernández-Cervantes, A.; Sertour, N.; Desseyn, J.-L.; Vincent, F.; Atanassova, R.; Gouyer, V.; Munro, C.A.; Bachellier-Bassi, S.; et al. Systematic gene overexpression in Candida albicans identifies a regulator of early adaptation to the mammalian gut. Cell. Microbiol. 2018, 20, e12890. [CrossRef]

47. Rine, J. Gene overexpression in studies of Saccharomyces cerevisiae. Methods Enzymol. 1991, 194, 239-251. [CrossRef]

48. Zordan, R.E.; Galgoczy, D.J.; Johnson, A.D. Epigenetic properties of white-opaque switching in Candida albicans are based on a self-sustaining transcriptional feedback loop. Proc. Natl. Acad. Sci. USA 2006, 103, 12807-12812. [CrossRef]

49. Fu, Y.; Luo, G.; Spellberg, B.J.; Edwards, J.E.; Ibrahim, A.S. Gene overexpression/suppression analysis of candidate virulence factors of Candida albicans. Eukaryot. Cell 2008, 7, 483-492. [CrossRef]

50. Chauvel, M.; Nesseir, A.; Cabral, V.; Znaidi, S.; Goyard, S.; Bachellier-Bassi, S.; Firon, A.; Legrand, M.; Diogo, D.; Naulleau, C.; et al A Versatile overexpression strategy in the pathogenic yeast Candida albicans: Identification of regulators of morphogenesis and fitness. PLoS ONE 2012, 7, e45912. [CrossRef]

51. Magtanong, L.; Ho, C.H.; Barker, S.L.; Jiao, W.; Baryshnikova, A.; Bahr, S.; Smith, A.M.; Heisler, L.E.; Choy, J.S.; Kuzmin, E.; et al. Dosage suppression genetic interaction networks enhance functional wiring diagrams of the cell. Nat. Biotechnol. 2011, 29, 505-511. [CrossRef]

52. Zhu, H.; Bilgin, M.; Bangham, R.; Hall, D.; Casamayor, A.; Bertone, P.; Lan, N.; Jansen, R.; Bidlingmaier, S.; Houfek, T.; et al. Global analysis of protein activities using proteome chips. Science 2001, 293, 2101-2105. [CrossRef]

53. Németh, T.; Papp, C.; Vagvolgyi, C.; Chakraborty, T.; Gacser, A. Identification and characterization of a neutral locus for knock-in purposes in C. parapsilosis. Front. Microbiol. 2020, 11, 1194. [CrossRef] [PubMed]

54. Clinical and Laboratory Standards Institute. Reference Method for Broth Dilution Antifungal Susceptibility Testing of Yeasts, 4th ed.; approved standard; CLSI document M27-S4; Clinical and Laboratory Standards Institute: Wayne, PA, USA, 2012.

55. Clinical and Laboratory Standards Institute. Reference Method for Broth Dilution Antifungal Susceptibility Testing of Yeasts, 3rd ed.; approved standard; CLSI document M27-A3; Clinical and Laboratory Standards Institute: Wayne, PA, USA, 2008.

56. Gerami-Nejad, M.; Zacchi, L.F.; McClellan, M.; Matter, K.; Berman, J. Shuttle vectors for facile gap repair cloning and integration into a neutral locus in Candida albicans. Microbiology 2013, 159, 565-579. [CrossRef] [PubMed]

57. Igual, J.C.; Johnson, A.L.; Johnston, L.H. Coordinated regulation of gene expression by the cell cycle transcription factor Swi4 and the protein kinase C MAP kinase pathway for yeast cell integrity. EMBO J. 1996, 15, 5001-5013. [CrossRef] [PubMed]

58. Thompson, D.S.; Carlisle, P.L.; Kadosh, D. Coevolution of morphology and virulence in Candida species. Eukaryot. Cell 2011, 10, 1173-1182. [CrossRef]

59. Cleary, I.A.; Mulabagal, P.; Reinhard, S.M.; Yadev, N.P.; Murdoch, C.; Thornhill, M.H.; Lazzell, A.L.; Monteagudo, C.; Thomas, D.P.; Saville, S.P.; et al. Pseudohyphal regulation by the transcription factor Rfg1p in Candida albicans. Eukaryot. Cell 2010, 9, 1363-1373. [CrossRef]

60. Ryan, O.; Shapiro, R.S.; Kurat, C.F.; Mayhew, D.; Baryshnikova, A.; Chin, B.; Lin, Z.-Y.; Cox, M.J.; Vizeacoumar, F.; Cheung, D.; et al. Global gene deletion analysis exploring yeast filamentous growth. Science 2012, 337, 1353-1356. [CrossRef]

61. Lackey, E.; Vipulanandan, G.; Childers, D.S.; Kadosh, D. Comparative evolution of morphological regulatory functions in Candida species. Eukaryot. Cell 2013, 12, 1356-1368. [CrossRef]

62. Sudbery, P.; Gow, N.; Berman, J. The distinct morphogenic states of Candida albicans. Trends Microbiol. 2004, 12, 317-324. [CrossRef]

63. Li, Z.; Nielsen, K. Morphology changes in human fungal pathogens upon interaction with the host. J. Fungi 2017, 3, 66. [CrossRef]

64. O'Connor, L.; Caplice, N.; Coleman, D.C.; Sullivan, D.J.; Moran, G.P. Differential filamentation of Candida albicans and Candida dubliniensis Is governed by nutrient regulation of UME6 expression. Eukaryot. Cell 2010, 9, 1383-1397. [CrossRef]

65. Trofa, D.; Gácser, A.; Nosanchuk, J.D. Candida parapsilosis, an emerging fungal pathogen. Clin. Microbiol. Rev. 2008, 21, 606-625. [CrossRef]

66. Nobile, C.J.; Fox, E.P.; Nett, J.E.; Sorrells, T.R.; Mitrovich, Q.M.; Hernday, A.D.; Tuch, B.B.; Andes, D.R.; Johnson, A.D. A recently evolved transcriptional network controls biofilm development in Candida albicans. Cell 2012, 148, 126-138. [CrossRef] [PubMed]

67. Barchiesi, F.; Spreghini, E.; Tomassetti, S.; Della Vittoria, A.; Arzeni, D.; Manso, E.; Scalise, G. Effects of caspofungin against Candida guilliermondii and Candida parapsilosis. Antimicrob. Agents Chemother. 2006, 50, 2719-2727. [CrossRef]

68. Cappelletty, D.; Eiselstein-McKitrick, K. The echinocandins. Pharmacotherapy 2007, 27, 369-388. [CrossRef] [PubMed]

69. Pfaller, M.A.; Boyken, L.; Hollis, R.J.; Kroeger, J.; Messer, S.A.; Tendolkar, S.; Diekema, D.J. In vitro susceptibility of invasive isolates of Candida spp. to anidulafungin, caspofungin, and micafungin: Six years of global surveillance. J. Clin. Microbiol. 2008, 46, 150-156. [CrossRef]

70. Brown, G.D. Innate antifungal immunity: The key role of phagocytes. Annu. Rev. Immunol. 2011, 29, 1-21. [CrossRef] [PubMed]

71. Höfs, S.; Mogavero, S.; Hube, B. Interaction of Candida albicans with host cells: Virulence factors, host defense, escape strategies, and the microbiota. J. Microbiol. 2016, 54, 149-169. [CrossRef]

72. García-Rodas, R.; González-Camacho, F.; Rodríguez-Tudela, J.L.; Cuenca-Estrella, M.; Zaragoza, O. The interaction between Candida krusei and murine macrophages results in multiple outcomes, including intracellular survival and escape from killing. Infect. Immun. 2011, 79, 2136-2144. [CrossRef]

73. Ellerbroek, P.M.; Walenkamp, A.M.E.; Hoepelman, A.I.M.; Coenjaerts, F.E.J. Effects of the capsular polysaccharides of Cryptococcus neoformans on phagocyte migration and inflammatory mediators. Curr. Med. Chem. 2004, 11, 253-266. [CrossRef] 
74. Pereira, T.; de Barros, P.; Fugisaki, L.; Rossoni, R.; Ribeiro, F.; de Menezes, R.; Junqueira, J.; Scorzoni, L. Recent advances in the use of Galleria mellonella model to study immune responses against human pathogens. J. Fungi 2018, 4, 128. [CrossRef]

75. Braun, B.R.; Johnson, A.D. Control of filament formation in Candida albicans by the transcriptional repressor TUP1. Science 1997, 277, 105-109. [CrossRef] [PubMed]

76. Zhao, R.; Lockhart, S.R.; Daniels, K.; Soll, D.R. Roles of TUP1 in switching, phase maintenance, and phase-specific gene expression in Candida albicans. Eukaryot. Cell 2002, 1, 353-365. [CrossRef] [PubMed]

77. Hu, C.-J.; Bai, C.; Zheng, X.-D.; Wang, Y.-M.; Wang, Y. Characterization and functional analysis of the siderophore-iron transporter CaArn1p in Candida albicans. J. Biol. Chem. 2002, 277, 30598-30605. [CrossRef]

78. Murad, A.M.; Leng, P.; Straffon, M.; Wishart, J.; Macaskill, S.; MacCallum, D.; Schnell, N.; Talibi, D.; Marechal, D.; Tekaia, F.; et al. NRG1 represses yeast-hypha morphogenesis and hypha-specific gene expression in Candida albicans. EMBO J. 2001, 20, $4742-4752$. [CrossRef] [PubMed]

79. Wächtler, B.; Wilson, D.; Haedicke, K.; Dalle, F.; Hube, B. From attachment to damage: Defined genes of Candida albicans mediate adhesion, invasion and damage during interaction with oral epithelial cells. PLoS ONE 2011, 6, e17046. [CrossRef]

80. Sassanfar, M.; Samson, L. Identification and preliminary characterization of an O6-methylguanine DNA repair methyltransferase in the yeast Saccharomyces cerevisiae. J. Biol. Chem. 1990, 265, 20-25.

81. Xiao, W.; Derfler, B.; Chen, J.; Samson, L. Primary sequence and biological functions of a Saccharomyces cerevisiae O6methylguanine/O4-methylthymine DNA repair methyltransferase gene. EMBO J. 1991, 10, 2179-2186. [CrossRef]

82. Andersen, K.S.; Bojsen, R.; Sørensen, L.G.R.; Nielsen, M.W.; Lisby, M.; Folkesson, A.; Regenberg, B. Genetic basis for Saccharomyces cerevisiae biofilm in liquid medium. G3 Genes I Genomes I Genetics 2014, 4, 1671-1680. [CrossRef]

83. Tóth, R.; Tóth, A.; Papp, C.; Jankovics, F.; Vágvölgyi, C.; Alonso, M.F.; Bain, J.M.; Erwig, L.-P.; Gácser, A. Kinetic studies of Candida parapsilosis phagocytosis by macrophages and detection of intracellular survival mechanisms. Front. Microbiol. $2014,5,633$.

84. Brennan, M.; Thomas, D.Y.; Whiteway, M.; Kavanagh, K. Correlation between virulence of Candida albicans mutants in mice and Galleria mellonella larvae. FEMS Immunol. Med. Microbiol. 2002, 34, 153-157. [CrossRef]

85. Slater, J.L.; Gregson, L.; Denning, D.W.; Warn, P.A. Pathogenicity of Aspergillus fumigatus mutants assessed in Galleria mellonella matches that in mice. Med. Mycol. 2011, 49, S107-S113. [CrossRef] [PubMed]

86. Amorim-Vaz, S.; Delarze, E.; Ischer, F.; Sanglard, D.; Coste, A.T. Examining the virulence of Candida albicans transcription factor mutants using Galleria mellonella and mouse infection models. Front. Microbiol. 2015, 6, 367. [CrossRef] [PubMed]

87. Jacobsen, I.D. Galleria mellonella as a model host to study virulence of Candida. Virulence 2014, 5, 237-239. [CrossRef] [PubMed]

88. Bendel, C.M.; Hess, D.J.; Garni, R.M.; Henry-Stanley, M.; Wells, C.L. Comparative virulence of Candida albicans yeast and filamentous forms in orally and intravenously inoculated mice. Crit. Care Med. 2003, 31, 501-507. [CrossRef]

89. Mora-Montes, H.M.; Bates, S.; Netea, M.G.; Castillo, L.; Brand, A.; Buurman, E.T.; Díaz-Jiménez, D.F.; Jan Kullberg, B.; Brown, A.J.P.; Odds, F.C.; et al. A multifunctional mannosyltransferase family in Candida albicans determines cell wall mannan structure and host-fungus interactions. J. Biol. Chem. 2010, 285, 12087-12095. [CrossRef]

90. Erbs, P.; Exinger, F.; Jund, R. Characterization of the Saccharomyces cerevisiae FCY1 gene encoding cytosine deaminase and its homologue FCA1 of Candida albicans. Curr. Genet. 1997, 31, 1-6. [CrossRef]

91. Harcus, D.; Nantel, A.; Marcil, A.; Rigby, T.; Whiteway, M. Transcription profiling of cyclic AMP signaling in Candida albicans. Mol. Biol. Cell 2004, 15, 4490-4499. [CrossRef]

92. Xu, D.; Jiang, B.; Ketela, T.; Lemieux, S.; Veillette, K.; Martel, N.; Davison, J.; Sillaots, S.; Trosok, S.; Bachewich, C.; et al. Genome-wide fitness test and mechanism-of-action studies of inhibitory compounds in Candida albicans. PLOS Pathog. 2007, 3, e92. [CrossRef]

93. Percival-Smith, A.; Segall, J. Characterization and mutational analysis of a cluster of three genes expressed preferentially during sporulation of Saccharomyces cerevisiae. Mol. Cell. Biol. 1986, 6, 2443-2451. [CrossRef]

94. Nogi, Y.; Yano, R.; Dodd, J.; Carles, C.; Nomura, M. Gene RRN4 in Saccharomyces cerevisiae encodes the A12.2 subunit of RNA polymerase I and is essential only at high temperatures. Mol. Cell. Biol. 1993, 13, 114-122. [CrossRef]

95. Chaillot, J.; Cook, M.A.; Corbeil, J.; Sellam, A. Genome-wide screen for haploinsufficient cell size genes in the opportunistic yeast Candida albicans. G3 Genes I Genomes I Genetics 2017, 7, 355-360. [CrossRef] [PubMed]

96. Jones, D.G.L.; Rosamond, J. Isolation of a novel protein kinase-encoding gene from yeast by oligodeoxyribonucleotide probing. Gene 1990, 90, 87-92. [CrossRef]

97. Moura, D.J.; Castilhos, B.; Immich, B.F.; Cañedo, A.D.; Henriques, J.A.P.; Lenz, G.; Saffi, J. Kin3 protein, a NIMA-related kinase of Saccharomyces cerevisiae, is involved in DNA adduct damage response. Cell Cycle 2010, 9, 2220-2229. [CrossRef] [PubMed]

98. Pais, T.M.; Foulquié-Moreno, M.R.; Hubmann, G.; Duitama, J.; Swinnen, S.; Goovaerts, A.; Yang, Y.; Dumortier, F.; Thevelein, J.M. Comparative polygenic analysis of maximal ethanol accumulation capacity and tolerance to high ethanol levels of cell proliferation in yeast. PLoS Genet. 2013, 9, e1003548. [CrossRef]

99. Sellam, A.; Chaillot, J.; Mallick, J.; Tebbji, F.; Richard Albert, J.; Cook, M.A.; Tyers, M. The p38/HOG stress-activated protein kinase network couples growth to division in Candida albicans. PLoS Genet. 2019, 15, e1008052. [CrossRef]

100. Blankenship, J.R.; Fanning, S.; Hamaker, J.J.; Mitchell, A.P. An extensive circuitry for cell wall regulation in Candida albicans. PLOS Pathog. 2010, 6, e1000752. [CrossRef]

101. Yoshikawa, K.; Tanaka, T.; Ida, Y.; Furusawa, C.; Hirasawa, T.; Shimizu, H. Comprehensive phenotypic analysis of single-gene deletion and overexpression strains of Saccharomyces cerevisiae. Yeast 2011, 28, 349-361. [CrossRef] 
102. Swanson, M.S.; Malone, E.A.; Winston, F. SPT5, an essential gene important for normal transcription in Saccharomyces cerevisiae, encodes an acidic nuclear protein with a carboxy-terminal repeat. Mol. Cell. Biol. 1991, 11, 4286. [CrossRef]

103. Hadwiger, J.A.; Wittenberg, C.; Richardson, H.E.; de Barros Lopes, M.; Reed, S.I. A family of cyclin homologs that control the G1 phase in yeast. Proc. Natl. Acad. Sci. USA 1989, 86, 6255-6259. [CrossRef]

104. Wagner, A. Energy costs constrain the evolution of gene expression. J. Exp. Zool. Part. B Mol. Dev. Evol. 2007, 308B, 322-324. [CrossRef] 